The final published version of this article can be found at http://dx.doi.org/10.1016/j.tet.2010.05.083. 


\section{Graphical Abstract}

\section{Isocyanide Based Multicomponent Reactions of Oxazolidines and}

\section{Related Systems}

Robert W. Waller ${ }_{a^{*}}^{a}$ Louis J. Diorazio, ${ }^{b}$ Brian A. Taylor, ${ }^{b}$ William B. Motherwell ${ }^{a^{*}}$ and Tom D. Sheppard
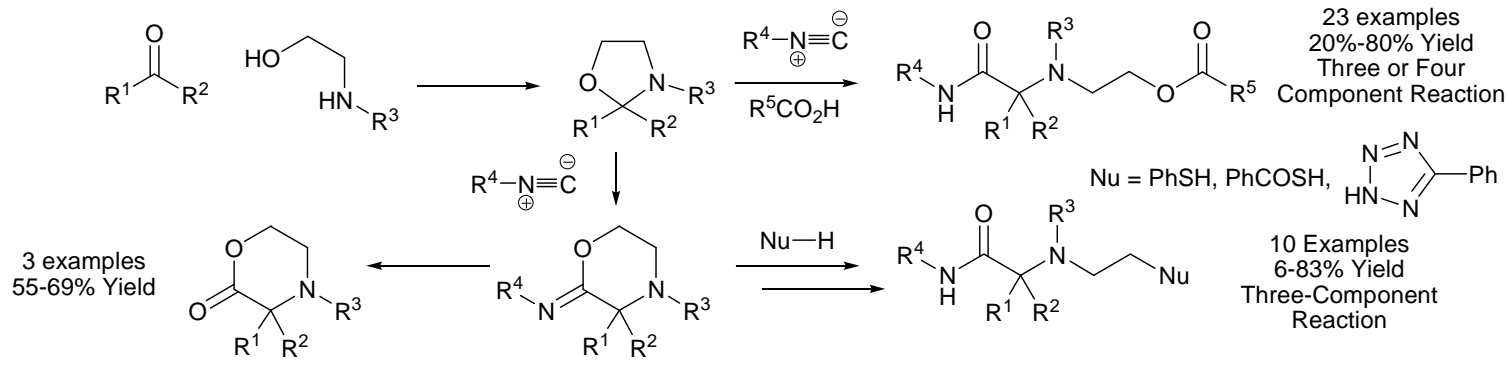


\title{
Isocyanide Based Multicomponent Reactions of Oxazolidines and Related Systems
}

\author{
Robert W. Waller, ${ }^{a}$ Louis J. Diorazio, ${ }^{b}$ Brian A. Taylor, ${ }^{b}$ William B. Motherwell ${ }^{a^{*}}$ and \\ Tom D. Sheppard
}

In celebration of the award of the Tetrahedron Prize to Professor Steven Ley.

${ }^{\mathrm{a}}$ Department of Chemistry, Christopher Ingold Laboratories, University College London, 20 Gordon Street, London, WC1H 0AJ, UK.

${ }^{\mathrm{b}}$ AstraZeneca Process R\&D, AstraZeneca, Silk Road Business Park, Macclesfield, SK10 2NA, UK.

\begin{abstract}
N$-Alkyloxazolidines react in a multicomponent reaction with carboxylic acids and isocyanides to give $N$-acyloxyethylamino acid amides. The previously reported reaction conditions were improved using a design of experiments approach (DoE). Under the optimized conditions, good yields of the $N$-acyloxyethylamino acid amide products are obtained both via a three or four component approach from $N$-alkylethanolamines, aldehydes/ketones, isocyanides and carboxylic acids. The reaction of oxazolidines without a nitrogen substituent was found to give either the expected Ugi products or the $N$-acyloxyethylamino acid amides depending on the choice of reaction conditions. Optimised reaction conditions were also developed for the ring-expansion of oxazolidines to morpholin-2-ones via reaction with an isocyanide followed by hydrolysis. The mechanistic pathway of the multicomponent reaction was briefly investigated using an ${ }^{18} \mathrm{O}$ labelling experiment. The carboxylic acid component can be replaced by a range of other acidic nucleophiles including thiobenzoic acid, thiophenol or 5-phenyl tetrazole, which are incorporated via an alternative pathway. These latter reactions can also be applied to 2-aminotetrahydrofurans, 2-aminotetrahydropyrans or 4-hydroxybut-2-one, further extending the structural diversity of the multicomponent reaction products.
\end{abstract}

Keywords Multicomponent reactions; Isocyanides; Design of Experiments; Oxazolidines; Ring-opening reactions

Multicomponent reactions (MCRs) are convergent reactions between three or more reactants in which all or most of the atoms in the starting materials form part of the final product. ${ }^{1}$ They are inherently atom economical processes in which relatively complex products can be obtained in a one-pot reaction from simple starting materials, and thus exemplify many of the desired features of an 'ideal synthesis'. Within this framework, isocyanide based multicomponent reactions (IMCRs) have provided a wealth of highly useful sequences for the assembly of compound libraries of particular interest to the pharmaceutical industry, and those which incorporate amino acid or hydroxyacid motifs through the use of the well known $\mathrm{Ugi}^{2}$ and Passerini ${ }^{3}$ reactions have proven to be especially valuable. The replacement of the carbonyl component in these reactions with a cyclic acetal unit could provide access to alternative multicomponent pathways, although reactions have, to date, been limited to simple isocyanide insertion into one of the C-O bonds. ${ }^{4}$ However, the application of bis-secondary diamines, ${ }^{5}$ $\mathrm{N}, \mathrm{O}$-acetals ${ }^{6}$ and glycolaldehyde dimer ${ }^{7}$ in novel IMCRs has been reported. Numerous reviews in recent years on the development and application of isocyanide based multicomponent reactions provide ample evidence of the burgeoning interest in this rapidly evolving research area, partly fuelled by the unique intellectual challenges posed by their design. ${ }^{8}$

We recently reported a novel three-component reaction (3-CR) between $N$-alkyl oxazolidines, isocyanides and carboxylic acids (Scheme 1). ${ }^{6}$ As part of our ongoing investigations into isocyanide based multicomponent reactions (IMCR), we now describe, in full detail, the optimisation of this reaction via a design of experiments (DoE) approach, enabling the reaction to be carried out successfully as a four component reaction in which the oxazolidine is generated in situ from a carbonyl compound and an ethanolamine. We also describe a mechanistic study and the extension of these multicomponent reactions to a wider range of $N, O$-acetals and nucleophilic components.

\section{Results and Discussion.}

Three-Component MCR of Oxazoldines, Isocyanides and Carboxylic Acids.

Initial reactions were carried out using an $N$-alkyloxazolidine, an isocyanide and a carboxylic acid with $10 \%$ $\mathrm{TsOH}$ as catalyst (Scheme 1), and gave reasonable to good yields of the $N$-acyloxyethylamino acid amides (Table 1) when the reactions were carried out at reflux in MeCN. ${ }^{6}$ A wide variety of oxazolidines, ${ }^{9}$ isocyanides and carboxylic acids were well tolerated and this reaction gives a complimentary structural skeleton to the ubiquitous Ugi and Passerini reactions. Thus, oxazoldines derived from both aromatic and aliphatic aldehydes bearing a variety of nitrogen substituents could be employed, together with alkyl and aryl isocyanides and alkyl 
or benzoic acids. The yields were good in most cases, although reactions with aryl isocyanides or those with a bulky nitrogen substitutent gave lower conversions. The reaction was extremely slow at room temperature and in the absence of an acid catalyst.

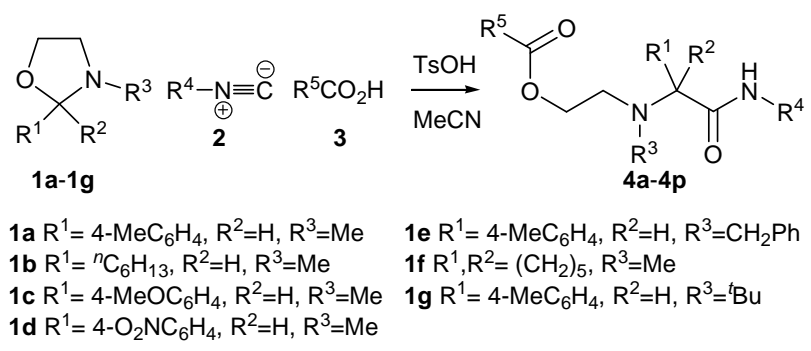

Scheme 1

Table 1. Three-component reactions of oxazolidines, isocyanides and carboxylic acids.

\begin{tabular}{|c|c|c|c|c|}
\hline Oxazolidinone & $\mathrm{R}^{4}$ & $\mathrm{R}^{5}$ & Yield & Product \\
\hline $1 \mathrm{a}$ & ${ }^{t} \mathrm{Bu}$ & $\mathrm{Ph}$ & $66 \%$ & $4 \mathbf{a}$ \\
\hline $1 \mathbf{a}$ & ${ }^{t} \mathrm{Bu}$ & Et & $64 \%$ & $4 b$ \\
\hline 1a & ${ }^{c} \mathrm{C}_{6} \mathrm{H}_{11}$ & $\mathrm{Ph}$ & $71 \%$ & $4 c$ \\
\hline 1a & ${ }^{i} \mathrm{Pr}$ & $\mathrm{Ph}$ & $73 \%$ & 4d \\
\hline $1 b$ & ${ }^{t} \mathrm{Bu}$ & $\mathrm{Ph}$ & $80 \%$ & $4 e$ \\
\hline 1b & ${ }^{t} \mathrm{Bu}$ & Et & $78 \%$ & $4 f$ \\
\hline $1 b$ & ${ }^{c} \mathrm{C}_{6} \mathrm{H}_{11}$ & $\mathrm{Ph}$ & $48 \%$ & $4 g$ \\
\hline $1 b$ & ${ }^{t} \mathrm{Bu}$ & $\begin{array}{c}2-(3- \\
\text { indole)ethy }\end{array}$ & $44 \%$ & $4 h$ \\
\hline $1 b$ & $\begin{array}{c}2,6- \\
\text { dimethylpheny }\end{array}$ & Et & $42 \%$ & $4 i$ \\
\hline $1 b$ & $\begin{array}{l}\text { 2-chloro-6- } \\
\text { methylphenyl }\end{array}$ & $\mathrm{Ph}$ & $29 \%$ & $4 j$ \\
\hline 1c & ${ }^{t} \mathrm{Bu}$ & $\mathrm{Ph}$ & $68 \%$ & $4 k$ \\
\hline 1d & ${ }^{t} \mathrm{Bu}$ & $\mathrm{Ph}$ & $47 \%$ & 41 \\
\hline 1e & ${ }^{t} \mathrm{Bu}$ & $\mathrm{Ph}$ & $44 \%$ & $4 m$ \\
\hline 1f & ${ }^{t} \mathrm{Bu}$ & $\mathrm{Ph}$ & $63 \%$ & $4 n$ \\
\hline $1 g$ & ${ }^{t} \mathrm{Bu}$ & $\mathrm{Me}$ & $20 \%$ & 40 \\
\hline $1 \mathrm{a}$ & ${ }^{t} \mathrm{Bu}$ & $\mathrm{Me}$ & $54 \%$ & $4 p^{a}$ \\
\hline
\end{tabular}

${ }^{\mathrm{a}}$ The reaction was carried out in ${ }^{i} \mathrm{PrOH}$ (see Scheme 7).

\section{Four-component MCR via in situ Oxazolidine Formation}

After the successful development of the three-component reaction between an $N$-alkyloxazolidine, isocyanide and carboxylic acid (Scheme 1), we reasoned that an in-situ preparation of the $N$-alkyloxazolidine in the presence of an isocyanide and carboxylic acid - a four-component reaction (4-CR) - should also be feasible. A brief study indicated that oxazolidine formation was essentially complete under the reaction conditions after 30 minutes. Unfortunately, the reaction between $n$-heptanal, $N$-methylethanolamine, tert-butyl isocyanide and benzoic acid gave a disappointing $13 \%$ yield of the desired four-component product $4 \mathbf{e}$ (Scheme 2). Lactone $\mathbf{5 a}$ was isolated as the major product $(25 \%)$ from this reaction. Close examination of the NMR spectra of the crude reaction mixtures of the earlier three-component reactions indicated that small quantities of morpholin-2-one products were also present, presumably due to traces of water in the reaction mixture. 


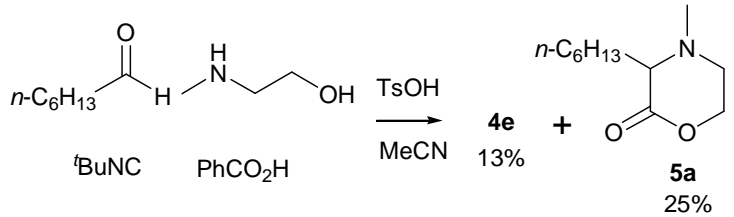

\section{Scheme 2}

When the reaction was carried out in the absence of the carboxylic acid, 5a was obtained in $36 \%$ yield. A possible mechanism for this bifurcated reaction pathway is shown in Scheme 3. Trapping of the iminium ion by the isocyanide leads to nitrilium cation $\mathbf{7}$ which can be expected to exist in equilibrium with cyclic iminoether 8 . Nucleophilic attack of a carboxylic acid on nitrilium cation $\mathbf{7}$ will lead to the multicomponent product $\mathbf{4}$ after subsequent acyl transfer in intermediate $\mathbf{9}$ (Path A). Alternatively, attack of the carboxylic acid on $\mathbf{8}$ could lead directly to the multicomponent product 4 via nucleophilic ring opening (Path B). ${ }^{10}$ Finally, competing hydrolysis of the cyclic intermediate $\mathbf{8}$ will lead to the morpholin-2-one product $\mathbf{5}$. The 4-CR presumably leads to the formation of a significant amount of morpholin-2-one due to the generation of one equivalent of water during the oxazolidine formation step.

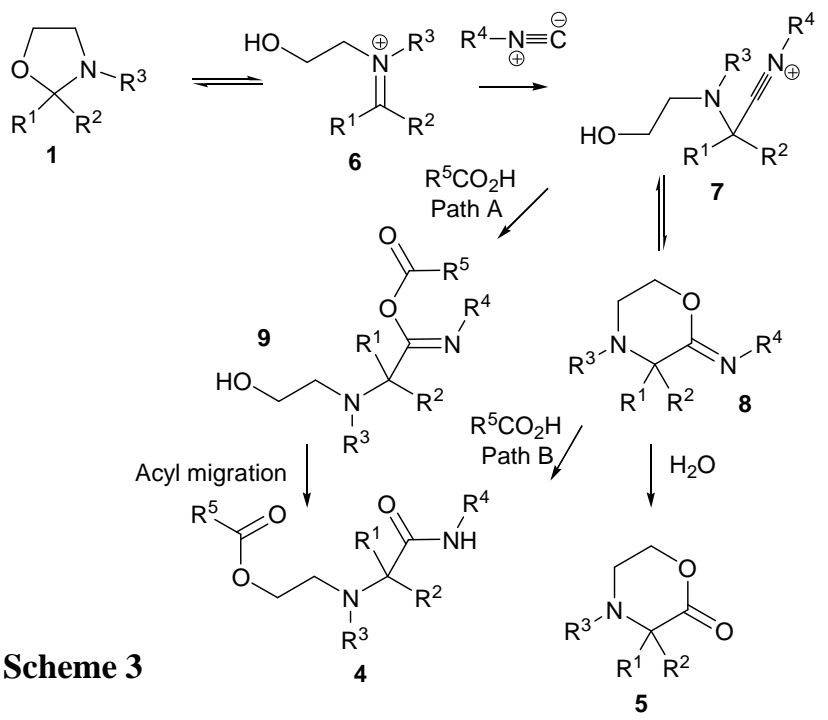

\subsection{Design of Experiments (DoE) Optimisation of the Multicomponent Reaction.}

At this stage in our investigation, we decided to use a Design of Experiments (DoE) approach ${ }^{11}$ in order to improve the yield of both the three and four component reactions. Initially we looked at developing conditions for the 3-CR, with the intention of being able to subsequently carry out the reaction as a four-component reaction, whilst minimising the formation of $\mathbf{5}$. DoE selects a wide ranging and diverse set of experiments in which the factors are independent of each other yet may be varied simultaneously. This results in a causal predictive model, which quantifies the importance of each factor plus any factor-factor interactions. DoE has seen extensive use in process chemistry in recent years and may be both more thorough and efficient than classical one variable at a time (OVAT) methods. ${ }^{11}$ The 3-CR to produce $\mathbf{4 m}$ (Scheme 4) was chosen as a good substrate for the DoE process as it resulted in a moderate yield of $44 \%$, giving plenty of scope for yield improvement, as well as a good chromophore for HPLC UV detection. MODDE $7^{\mathrm{TM}}$ software was used to design a set of reactions. The factors chosen for variation and the levels employed are shown in Table 2. The effect of the factors on the yield of both $\mathbf{4 m}$ and $\mathbf{5 b}$ was investigated.<smiles>Cc1ccc(C2C(=O)OCCN2Cc2ccccc2)cc1</smiles>

1e

\section{Scheme 4.}

\subsubsection{Design of Experiments (DoE) \#1}


We embarked upon a mixed level fractional factorial experimental design (resolution III), with one factor at four levels and five factors at two levels allowing main factors to be assessed for importance, this was carried out as 16 experiments plus four control experiments (Table 3). Yields of $\mathbf{4 m}$ and $\mathbf{5 b}$ were determined by HPLC UV peak area integration relative to 1,1,1-trifluorotoluene internal standard.

Table 2. Variables considered, with levels employed in design (DOE \#1).

\begin{tabular}{ccccc}
\hline & Variable & $(-)$ & 0 & $(+)$ \\
\hline A & Temperature $\left({ }^{\circ} \mathrm{C}\right)$ & 60 & N/A & 80 \\
B & Solvent Concentration (M) & 0.2 & 0.3 & 0.4 \\
C & Benzoic Acid (equivalents) & 1 & 1.25 & 1.5 \\
D & Acid Catalyst (mol\%) & 2 & 6 & 10 \\
E & Isocyanide (equivalents) & 1 & 1.25 & 1.5 \\
F & Solvent Type (4 types) ${ }^{\mathrm{a}}$ & - & - & - \\
\hline a (i)-Ani & & & &
\end{tabular}

${ }^{\mathrm{a}}$ (i)-Anisole (ii)-EtOAc (iii)- ${ }^{\mathrm{i}} \mathrm{PrOH}$ (iv)- $\mathrm{MeCN}$

The data was analysed using MODDE $7^{\mathrm{TM}}$ software by a partial least squares fitting model (PLS). This resulted in two models, the first for $\mathbf{4 m}$ where $\mathrm{R}^{2}=0.922$ and $\mathrm{Q}^{2}=0.844$ and a second model for $\mathbf{5 b}$ where $\mathrm{R}^{2}=0.897$ and $\mathrm{Q}^{2}=0.711$ respectively.

Table 3 Experimental plan and results (DOE \#1).

\begin{tabular}{|c|c|c|c|c|c|c|c|c|}
\hline \# & A & B & $\mathrm{C}$ & D & $\mathrm{E}$ & $\mathrm{F}$ & Yield 4m & Yield $\mathbf{5 b}$ \\
\hline 1 & - & - & - & + & + & $\mathrm{i}$ & $48 \%$ & $26 \%$ \\
\hline 2 & + & - & - & + & + & ii & $44 \%$ & $23 \%$ \\
\hline 3 & - & - & - & - & - & iii & $65 \%$ & $18 \%$ \\
\hline 4 & + & - & - & - & - & iv & $67 \%$ & $30 \%$ \\
\hline 5 & + & + & - & - & + & $\mathrm{i}$ & $38 \%$ & $18 \%$ \\
\hline 6 & - & + & - & - & + & ii & $36 \%$ & $16 \%$ \\
\hline 7 & + & + & - & + & - & iii & $64 \%$ & $30 \%$ \\
\hline 8 & - & + & - & + & - & iv & $61 \%$ & $36 \%$ \\
\hline 9 & + & - & + & + & - & $\mathrm{i}$ & $47 \%$ & $27 \%$ \\
\hline 10 & - & - & + & + & - & ii & $38 \%$ & $17 \%$ \\
\hline 11 & + & - & + & - & + & iii & $74 \%$ & $14 \%$ \\
\hline 12 & - & - & + & - & + & iv & $68 \%$ & $21 \%$ \\
\hline 13 & - & + & + & - & - & $\mathrm{i}$ & $54 \%$ & $24 \%$ \\
\hline 14 & + & + & + & - & - & ii & $33 \%$ & $13 \%$ \\
\hline 15 & - & + & + & + & + & iii & $68 \%$ & $25 \%$ \\
\hline 16 & + & + & + & + & + & iv & $57 \%$ & $29 \%$ \\
\hline 17 & - & 0 & 0 & 0 & 0 & ii & $41 \%$ & $18 \%$ \\
\hline 18 & - & 0 & 0 & 0 & 0 & ii & $42 \%$ & $18 \%$ \\
\hline 19 & + & 0 & 0 & 0 & 0 & ii & $40 \%$ & $19 \%$ \\
\hline 20 & + & 0 & 0 & 0 & 0 & ii & $38 \%$ & $18 \%$ \\
\hline
\end{tabular}

The data from the models is viewed as a scaled and centered coefficient plot where the sign and size of each coefficient bar shows the relative effect on the yield and thus the relative importance of the factor in the model. 


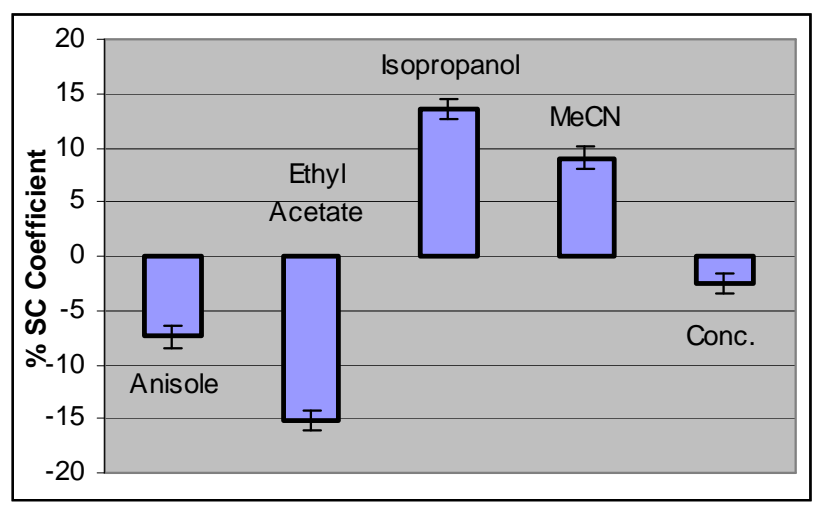

Graph 1. Scaled and centred coefficients for $\mathbf{4 m}$ yield.

For the formation of $\mathbf{4 m}$, temperature and equivalents of benzoic acid, $\mathrm{TsOH}$ and isocyanide had no statistical effect within the parameters investigated. Graph 1 shows that choice of solvent is the most significant factor affecting the yield of $\mathbf{4 m}$, with isopropanol and to a lesser degree acetonitrile, being superior. Concentration of reactants had a smaller effect within the range investigated.

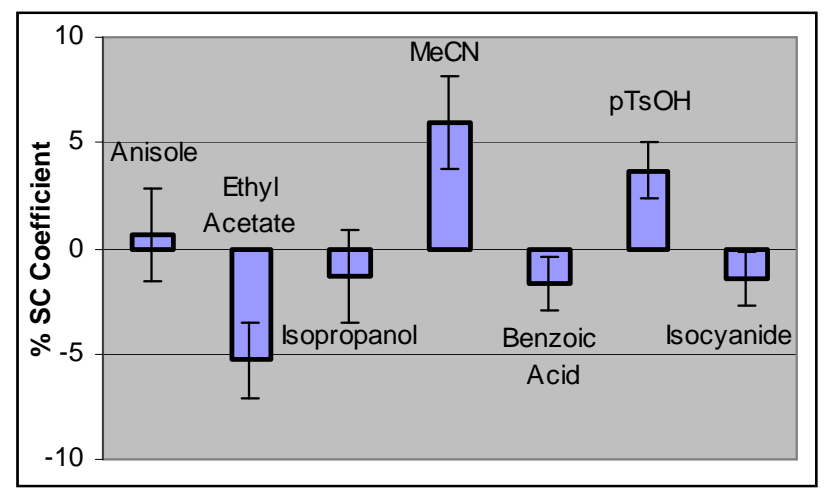

Graph 2. Scaled and centred coefficients for $\mathbf{5 b}$ yield.

Graph 2 indicates that the factors affecting the yield of lactone $\mathbf{5 b}$ are solvent and TsOH loading. The use of acetonitrile as solvent and a higher loading of TsOH results in an increased yield of $\mathbf{5 b}$. The two models together reveal that for a cleaner higher yielding preparation of $\mathbf{4 m}$ in the presence of some water, isopropanol should be selected as solvent, since it favours the formation of $\mathbf{4 m}$ and disfavours the formation of $\mathbf{5 b}$. A lower loading of $\mathrm{TsOH}$ is also desirable, as it has no effect on the yield of $\mathbf{4 m}$, whilst a higher level favours the formation of side product 5b. The lower temperature of $60^{\circ} \mathrm{C}$ may also be used, as there is no benefit indicated by the use of a higher temperature. However it should again be noted that initial work showed that this reaction was very slow at room temperature or in the absence of an acid catalyst. The new conditions obtained from the DoE study were expected to reduce the amount of lactone $\mathbf{5 b}$ produced by hydrolysis of intermediate $\mathbf{8}$. We therefore investigated whether we could apply these conditions to the four-component reaction. Initial experiments to determine the rapidity of the oxazolidine formation in isopropanol were encouraging, with over $80 \%$ conversion to the oxazolidine observed within 30 minutes under the reaction conditions. Satisfyingly when the 4-CR was attempted between an ethanolamine, aldehyde, isocyanide and carboxylic acid, a yield akin to the 3-CR was obtained in most cases (Table 4).

Table 4. Four-component reactions of aminoalcohols, aldehydes, isocyanides and carboxylic acids.

\begin{tabular}{ccccccc}
\hline $\mathrm{R}_{1}$ & $\mathrm{R}_{2}$ & $\mathrm{R}_{3}$ & $\mathrm{R}_{4}$ & $\mathrm{R}_{5}$ & Yield & Product \\
\hline $4-\mathrm{Me}-\mathrm{C}_{6} \mathrm{H}_{4}$ & $\mathrm{H}$ & $\mathrm{Me}$ & ${ }^{t} \mathrm{Bu}$ & $\mathrm{Ph}$ & $68 \%$ & $\mathbf{4 a}$ \\
${ }^{n} \mathrm{C}_{6} \mathrm{H}_{13}$ & $\mathrm{H}$ & $\mathrm{Me}$ & ${ }^{t} \mathrm{Bu}$ & $\mathrm{Ph}$ & $56 \%$ & $\mathbf{4 e}$ \\
$4-\mathrm{MeO}-\mathrm{C}_{6} \mathrm{H}_{4}$ & $\mathrm{H}$ & $\mathrm{Me}$ & ${ }^{t} \mathrm{Bu}$ & $\mathrm{Ph}$ & $66 \%$ & $\mathbf{4 k}$ \\
$4-\mathrm{O}_{2} \mathrm{~N}_{-} \mathrm{C}_{6} \mathrm{H}_{4}$ & $\mathrm{H}$ & $\mathrm{Me}$ & ${ }^{t} \mathrm{Bu}$ & $\mathrm{Ph}$ & $30 \%$ & $\mathbf{4 l}$ \\
${ }^{n} \mathrm{C}_{6} \mathrm{H}_{13}$ & $\mathrm{H}$ & $\mathrm{Me}$ & ${ }^{c} \mathrm{C}_{6} \mathrm{H}_{11}$ & $\mathrm{Ph}$ & $43 \%$ & $\mathbf{4 g}$ \\
\hline
\end{tabular}




\subsection{Application of Bifunctional Substrates}<smiles>O=Cc1ccccc1C(=O)O</smiles>

10<smiles>[R]NCCO</smiles><smiles>CCCNC(=O)C1NCCOC(=O)c2ccccc21</smiles>

$12 \mathrm{R}^{1}={ }^{\circ} \mathrm{C}_{6} \mathrm{H}_{11}, \mathrm{R}^{2}=\mathrm{Me} 33 \%$ $13 \mathrm{R}^{1}={ }^{\mathrm{t}} \mathrm{Bu}, \mathrm{R}^{2}=\mathrm{CH}_{2} \mathrm{Ph} 25 \%$<smiles>CNCCOCC(=O)OCC(=O)Oc1ccccc1C=O</smiles>

\section{Scheme 5}

The new reaction conditions were also applied to the synthesis of medium ring products in moderate yield via incorporation of the bifunctional acid-aldehyde components $\mathbf{1 0}$ and $\mathbf{1 1}$ (Scheme 5). ${ }^{12}$ These reactions were unsuccessful at high temperature, but the multicomponent reaction products 12-14 were obtained in moderate yield on stirring the reactions for prolonged periods at room temperature.

\subsection{Design of Experiments (DoE) \#2 Morpholinone synthesis.}

We then directed our attention to optimizing the conditions for the ring expansion of oxazolidines to morpholinones by the reaction of an oxazolidine with $t$-butyl isocyanide (Scheme 6). Model 2 in DoE \#1 (Graph 2 ) indicates that the formation of $\mathbf{5 b}$ is favoured by a polar aprotic solvent (acetonitrile) and a higher loading of TsOH. These factors were further investigated using a second design of experiments (DoE) process. The selected variables in this study were solvent type (2 levels), $\mathrm{TsOH}$ acid catalyst loading and isocyanide loading (Table 5). Preliminary studies of polar aprotic solvents suggested sulfolane and DMSO to be superior solvents to $\mathrm{MeCN}$ for the study; DMF was unsuitable. A full factorial experimental design (resolution V) with three factors with each at two levels, allowing main factors and interaction between factors to be assessed for importance, was carried out as eight experiments plus two control experiments (Table 6). Yields of 5b were determined by HPLC UV peak area integration relative to 1,1,1-trifluorotoluene internal standard at the three reaction times given in Table 6.

Table 5. Variables considered, with levels employed in DOE \#2.

\begin{tabular}{ccccc}
\hline & Variable & $(-)$ & 0 & $(+)$ \\
\hline A & Acid Catalyst (mol\%) & 10 & 30 & 50 \\
B & Isocyanide (equivalents) & 1 & 1.25 & 1.5 \\
C & Solvent Type (2 types) ${ }^{\mathrm{a}}$ & - & - & - \\
\hline
\end{tabular}

${ }^{a}$ (i)-DMSO (ii)-Sulfolane 
Table 6. Experimental plan and yields of $\mathbf{5 b}$ (DOE \#2).

\begin{tabular}{ccccccc}
\hline$\#$ & A & B & C & $4 \mathrm{~h}$ & $22 \mathrm{~h}$ & $44 \mathrm{~h}$ \\
\hline 1 & - & - & i & $0 \%$ & $15 \%$ & $26 \%$ \\
2 & - & - & ii & $0 \%$ & $3 \%$ & $4 \%$ \\
3 & + & - & i & $4 \%$ & $26 \%$ & $38 \%$ \\
4 & + & - & ii & $8 \%$ & $23 \%$ & $29 \%$ \\
5 & - & + & i & $0 \%$ & $16 \%$ & $27 \%$ \\
6 & - & + & ii & $0 \%$ & $7 \%$ & $9 \%$ \\
7 & + & + & i & $7 \%$ & $33 \%$ & $51 \%$ \\
8 & + & + & ii & $12 \%$ & $24 \%$ & $36 \%$ \\
9 & 0 & 0 & i & $4 \%$ & $28 \%$ & $41 \%$ \\
10 & 0 & 0 & i & $5 \%$ & $30 \%$ & $43 \%$ \\
\hline
\end{tabular}

The data was analysed to give a model where $\mathrm{R}^{2}=0.892$ and $\mathrm{Q}^{2}=0.781$.

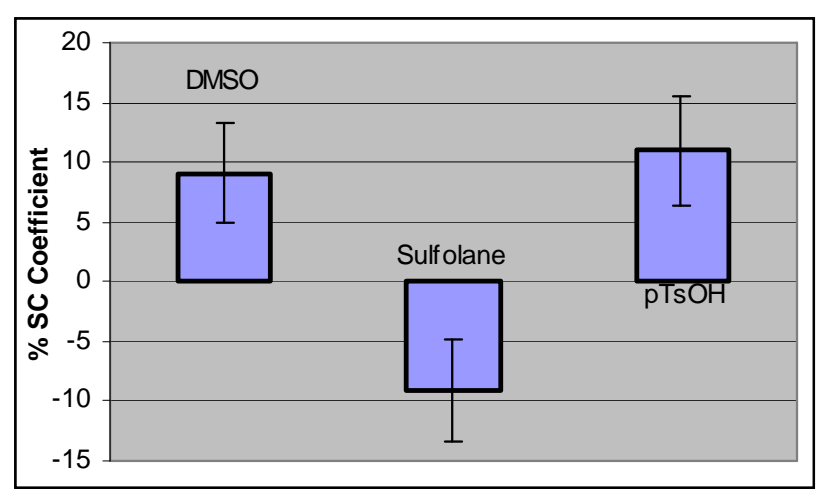

Graph 3. Scaled and centred coefficients for morpholin-2-one formation.

The results of the $2^{\text {nd }}$ DoE (Graph 3) show that solvent type is again an important factor, with DMSO superior to sulfolane. The loading of $\mathrm{TsOH}$ is also a factor, with a greater loading resulting in a higher yield. Isocyanide loading again had no effect within the levels studied. When the loading of $\mathrm{TsOH}$ was increased to 1.1 equivalents, reasonable yields of morpholinones $\mathbf{5 a - 5 c}$ could be obtained (Scheme 6).

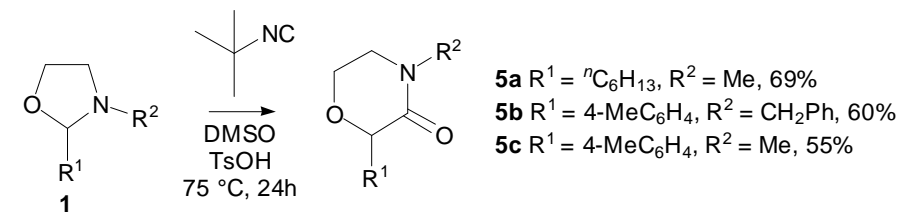

Scheme 6.

\subsection{Mechanistic Studies}

Scheme 3 shows two feasible, alternative mechanisms for the reaction between an $N$-alkyloxazolidine, an isocyanide and a carboxylic acid to give the 4-CR product 4 . To clarify the mechanism, ${ }^{18} \mathrm{O}$-labelled acetic acid was used as the acid component in an MCR with oxazolidinone 1a and tert-butyl isocyanide to give $\mathbf{4} \mathbf{p}-{ }^{18} \boldsymbol{O}_{2}$ (Scheme 7).<smiles>CC(=O)OCCN(C)C(C(=O)NCc1ccccc1)c1ccc(C)cc1</smiles> 


\section{Scheme 7}

The position of the labelled oxygen atoms in the product of this reaction will be different depending on the mechanistic pathway followed (Scheme 8). Both carbonyl oxygens in the product will be labelled if path A is followed - (attack of the acylium ion by the carboxylic acid anion followed by $O$-acyl migration), while both oxygen atoms in the ester group will be labelled via path B (acid catalysed ring opening by nucleophilic attack at the $\mathrm{sp}^{3}$ carbon). Careful comparison of the mass spectrum of the product from the labelling experiment with the unlabelled product $4 \mathbf{p}$ strongly suggested that product $\mathbf{4 p}-{ }^{18} \mathrm{O}_{2}$ contains ${ }^{18} \mathrm{O}$ labels at the two carbonyl oxygens, as evidenced by the mass observed for the fragment 19. This indicates that carboxylic acids react via route $\mathrm{A}-$ trapping the acylium ion with subsequent $\mathrm{O}$-acyl migration, which may occur in either the intra- or intermolecular mode.

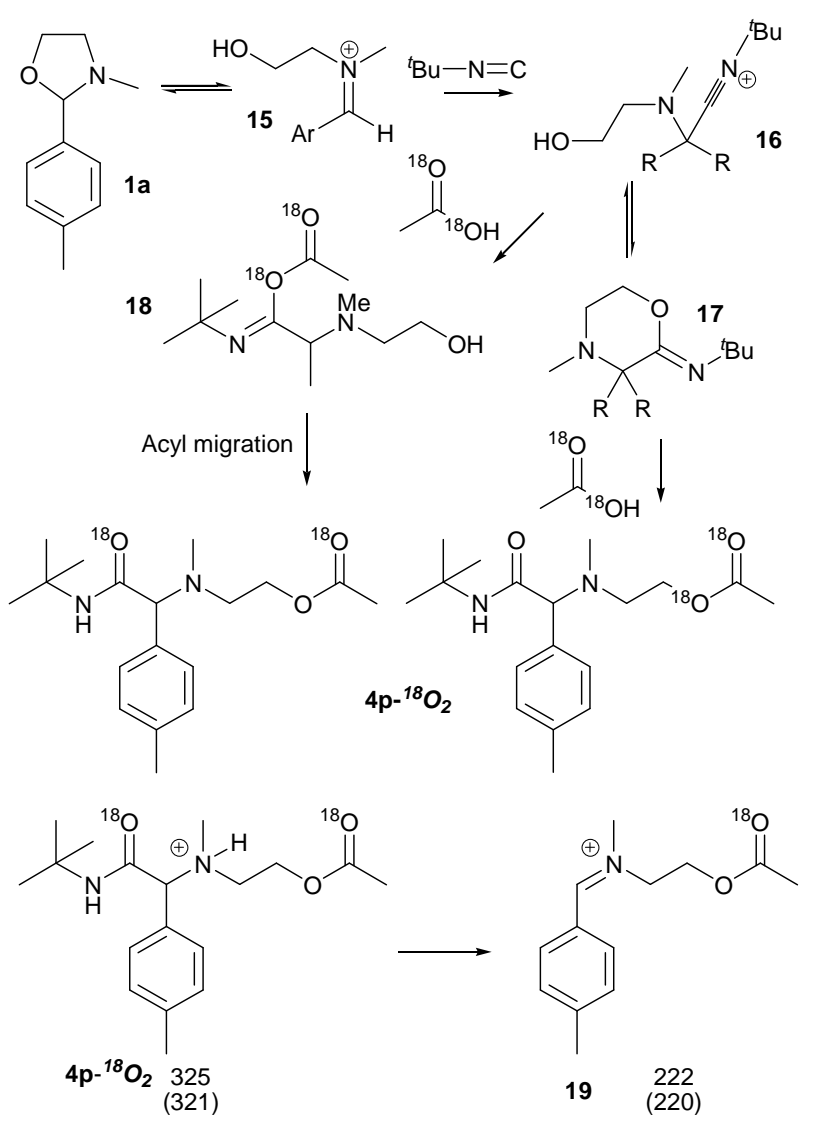

\section{Scheme 8}

The cyclic intermediate $\mathbf{2 0}$ could be isolated in $73 \%$ yield when 2,6-dimethylphenyl isocyanide was reacted with $\mathbf{1 b}$ in the absence of a carboxylic acid (Scheme 9). It is thought that the electronic stabilisation provided by the aryl group, together with the increased steric hindrance due to the presence of the methyl groups results in a higher stability. Heterocycle $\mathbf{2 0}$ was stable in air for more than three months at room temperature but could be converted into product $4 \mathbf{i}$ by heating with propionic acid in the presence of $\mathrm{TsOH}$ in $i-\mathrm{PrOH}$.

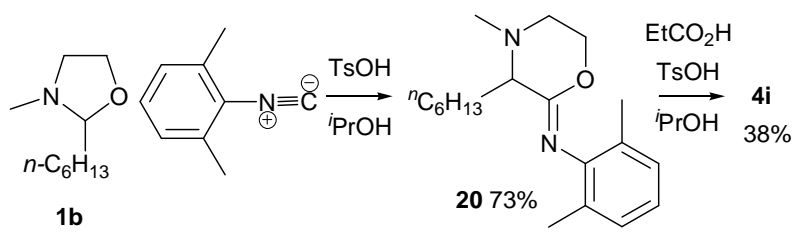

\section{Scheme 9}




\subsection{Use of Oxazolidines Derived from Ethanolamine.}

Initial attempts during the early stages of our research to use oxazolidine (21a) ${ }^{13}$ in the 3-CR with $\mathrm{MeCN}$ as solvent resulted in a complex mixture of products. However, Ugi reactions using unprotected ethanolamine have been reported to occur in high yield in $\mathrm{MeOH}$ at room temperature in the absence of an acid catalyst. ${ }^{14}$ After optimization of our reaction conditions using DoE, we decided to reinvestigate the reaction of oxazolidine 21a, expecting to see the formation of Ugi product $\mathbf{2 3}$ as previously reported (Scheme 10). ${ }^{14}$ We were therefore extremely surprised to obtain moderate yields of the $O$-acyl migration product 22a, with no detectable quantity of the Ugi product 23 (Scheme 10). This is somewhat unexpected, as acyl transfer to the amino group in the intermediate would be expected to be much faster than acyl transfer to the hydroxyl group due to the greater nucleophilicity of nitrogen and the more favourable 5-exo-trig transition state (as opposed to 7-exo-trig arrangement required for the O-acyl transfer). Interestingly, when the same reaction was carried out in methanol at room temperature, only the Ugi product $\mathbf{2 3}$ was obtained. A series of experiments were carried out to investigate the effect of temperature, solvent type and concentration on the yields of the two possible products of this reaction. By varying the solvent and/or temperature mixtures of the two products could be obtained. The $\mathrm{TsOH}$ catalyst is unnecessary for either reaction, in fact resulting in slightly lower yields.<smiles>[R]OCCN([R])C(C(=O)NC(C)(C)C)c1ccc(C)cc1</smiles>

\section{Scheme 10}

Table 7. Three-component reactions of oxazolidine 21a

\begin{tabular}{ccccccc}
\hline $\begin{array}{c}\text { Temp } \\
\left({ }^{\circ} \mathrm{C}\right)\end{array}$ & Solvent & $\begin{array}{c}\text { Conc. } \\
(\mathrm{M})\end{array}$ & $\begin{array}{c}\text { Time } \\
(\mathrm{h})\end{array}$ & $\begin{array}{c}\text { TsOH } \\
(\mathrm{mmol})\end{array}$ & $\begin{array}{c}\mathbf{2 2 a} \\
(\%)\end{array}$ & $\begin{array}{c}\mathbf{2 3} \\
(\%)\end{array}$ \\
\hline 82 & $i \mathrm{PrOH}$ & 1 & 18 & 2 & 57 & - \\
25 & $\mathrm{MeOH}$ & 0.4 & 42 & 2 & - & 81 \\
82 & $i \mathrm{PrOH}$ & 1 & 18 & 0 & 70 & - \\
25 & $\mathrm{MeOH}$ & 0.4 & 42 & 0 & - & 90 \\
82 & $\mathrm{MeCN}$ & 1 & 18 & 2 & - & - \\
78 & $\mathrm{EtOH}$ & 1 & 18 & 0 & 30 & 32 \\
65 & $\mathrm{MeOH}$ & 0.4 & 18 & 0 & - & 80 \\
45 & $\mathrm{MeOH}$ & 0.4 & 18 & 0 & - & 84 \\
25 & $\mathrm{EtOH}$ & 1 & 42 & 0 & - & 71 \\
25 & $i \mathrm{PrOH}$ & 1 & 42 & 0 & - & 66 \\
25 & $i \mathrm{PrOH}$ & 0.4 & 42 & 0 & - & 60
\end{tabular}

In general lower temperatures and the use of more polar solvents favoured the Ugi product 23, whereas heating in less polar alcohols led to a preference for the $O$-acyl migration product 22a. Our initial hypothesis was that the ester product 22a was formed by acyl transfer from nitrogen to oxygen when the reaction was heated. However, on heating Ugi product $\mathbf{2 3}$ to reflux for $18 \mathrm{~h}$ in the presence of $10 \% \mathrm{TsOH}$ only trace amounts of the ester $\mathbf{2 2 a}$ were observed. No conversion was observed at all in the absence of the acid catalyst suggesting that the ester 22a cannot be derived from amide $\mathbf{2 3}$ in the multicomponent reaction. A possible explanation is that the nitrogen atom is able to act as a general base for the $\mathrm{OH}$ in refluxing ${ }^{i} \mathrm{PrOH}$, but this process is disfavoured by hydrogen bonding to the solvent in $\mathrm{MeOH}$. Moderate to good yields of the esters 22a-22d could be obtained from the ethanolamine derived oxazolidines 21a and 21b (Scheme 11 and Table 8). ${ }^{13}$

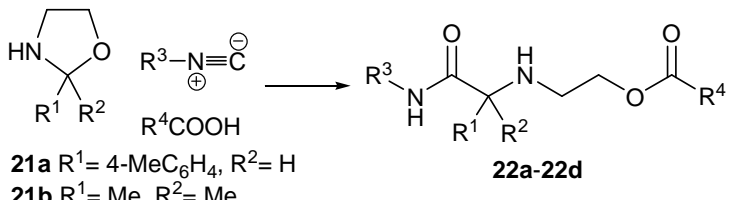

\section{Scheme 11}


Table 8. Three-component reactions of ethanolamine derived oxazolidines, isoyanides and carboxylic acids.

\begin{tabular}{ccccc}
\hline Oxazolidinone & $\mathrm{R}^{3}$ & $\mathrm{R}^{4}$ & Yield & Product \\
\hline 21a & ${ }^{t} \mathrm{Bu}$ & $\mathrm{Ph}$ & $90 \%$ & 22a \\
21b & ${ }^{t} \mathrm{Bu}$ & $\begin{array}{c}\text { 2-(3-indole) } \\
\text { ethyl }\end{array}$ & $38 \%$ & $\mathbf{2 2 b}$ \\
& & $\mathrm{Ph}$ & $37 \%$ & 22c \\
21b & ${ }^{c} \mathrm{C}_{6} \mathrm{H}_{11}$ & $\mathrm{Ph}$ & $37 \%$ & 22d \\
21b & ${ }^{t} \mathrm{Bu}$ & & & \\
\hline
\end{tabular}

\subsection{Alternative Nucleophiles for the Oxazolidine 3-CR}

Thioacids have been previously employed in isocyanide based multicomponent reactions as alternatives to carboxylic acids. ${ }^{15}$ We were keen to examine their use in an oxazolidine MCR to determine whether the softer nature of the thioacid might favour the alternative ring-opening pathway (Path B, Scheme 3). ${ }^{10}$ Pleasingly, when thiobenzoic acid was employed in a 3-CR with oxazolidine 1a and tert-butyl isocyanide, product $\mathbf{2 4}$ was obtained in 20\% yield, in which the intermediate 8 has undergone an $\mathrm{S}_{\mathrm{N}} 2$ ring opening reaction (Scheme 12).

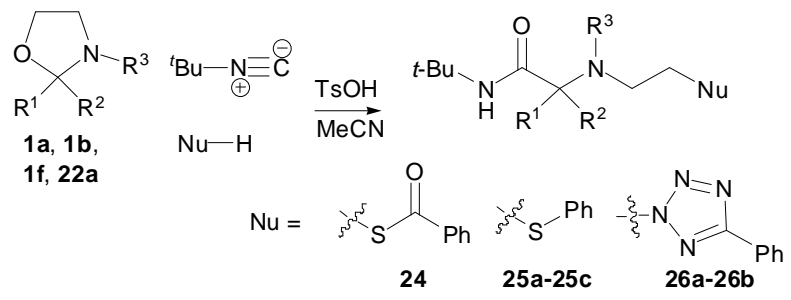

\section{Scheme 12}

This result led us to investigate other soft nucleophiles as potential components for the oxazolidine IMCR (Scheme 12 and Table 9). Gratifyingly, multicomponent products could also be obtained successfully with thiophenol and 5-phenyltetrazole. In the latter case, only a single regioisomer (assigned as $\mathbf{2 6}$ on the basis of Noe experiments) of the tetrazole product was obtained. We are currently investigating the scope of this variation of our 3-CR as the incorporation of aromatic heterocycles as components in an MCR could be of great potential utility in pharmaceutical library synthesis. The role of the cyclic intermediate $\mathbf{8}$ as a trap for a diverse range of nucleophiles, circumvents one of the major limitations of Ugi-type reactions: the requirement for the formation of a stable $\alpha$-adduct after nucleophilic attack on the acylium ion. Potentially, almost any nucleophile could be incorporated into the reaction, through suitable choice of conditions, as the ring-opening process is likely to be thermodynamically favourable due to formation of the stable amide bond. This novel reaction pathway is complementary to both the Mumm rearrangement in the Ugi reaction and the Smiles rearrangement in recently reported IMCRs of phenols and related derivatives. ${ }^{16}$

Table 9. Three-component reactions of oxazolidines, isocyanides and nucleophiles.

\begin{tabular}{cccccc}
\hline \multicolumn{1}{c}{$\mathrm{R}^{1}$} & $\mathrm{R}^{2}$ & $\mathrm{R}^{3}$ & $\mathrm{Nu}$ & Yield & Product \\
\hline $4-\mathrm{MeC}_{6} \mathrm{H}_{4}$ & $\mathrm{H}$ & $\mathrm{Me}$ & $\mathrm{PhCSOH}$ & $20 \%$ & $\mathbf{2 4}$ \\
${ }^{n} \mathrm{C}_{6} \mathrm{H}_{13}$ & $\mathrm{H}$ & $\mathrm{Me}$ & $\mathrm{PhSH}$ & $59 \%$ & $\mathbf{2 5 a}$ \\
$\left(\mathrm{CH}_{2}\right)_{5}$ & $\mathrm{Me}$ & $\mathrm{PhSH}$ & $29 \%$ & $\mathbf{2 5 b}$ \\
$4-\mathrm{MeC}_{6} \mathrm{H}_{4}$ & $\mathrm{H}$ & $\mathrm{H}$ & $\mathrm{PhSH}$ & $6 \%$ & $\mathbf{2 5 c}$ \\
${ }^{n} \mathrm{C}_{6} \mathrm{H}_{13}$ & $\mathrm{H}$ & $\mathrm{Me}$ & $\begin{array}{c}5 \text {-phenyl-1H- } \\
\text { tetrazole }\end{array}$ & $71 \%$ & $\mathbf{2 6 \mathbf { a } ^ { \mathrm { a } }}$ \\
$4-\mathrm{MeC}_{6} \mathrm{H}_{4}$ & $\mathrm{H}$ & $\mathrm{Me}$ & $\begin{array}{c}5 \text {-phenyl-1H- } \\
\text { tetrazole }\end{array}$ & $67 \%$ & $\mathbf{2 6 \mathbf { b } ^ { \mathrm { a } }}$ \\
\hline
\end{tabular}

${ }^{\mathrm{a}}$ The product was assigned as the 1,4 substituted tetrazole isomer.

\subsection{Extension to other $N, O$ acetals}

We briefly examined the extension of these novel multicomponent reactions to $\mathrm{N}, \mathrm{O}$-acetals $\mathbf{2 7}$ and $\mathbf{2 8}$ (Scheme 13) ${ }^{17}$ Pleasingly, the three-component reactions between these systems, tert-butyl isocyanide and 5-phenyl-1Htetrazole led to the formation of the expected multicomponent products $\mathbf{2 9}$ and $\mathbf{3 0}$ in good yield. These reactions presumably proceed via ring-opening of the intermediates $\mathbf{3 1}$ and $\mathbf{3 2}$ respectively. 


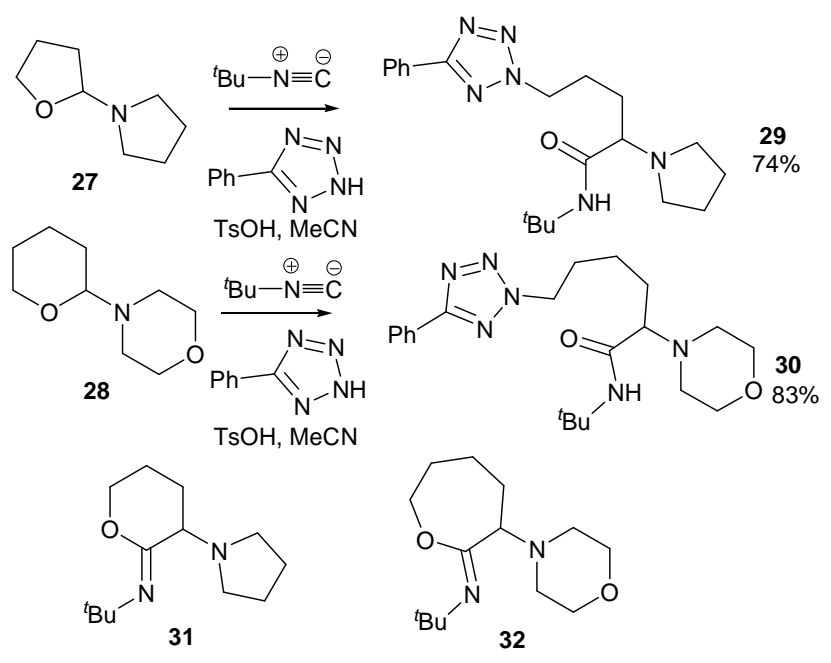

Scheme 13

Similar reactions could also be carried out via 4-component condensation of benzylamine, 4-hydroxybut-2-one $\mathbf{3 3}$, tert-butyl isocyanide and either thiophenol or 5-phenyl-1H-tetrazole to give the products $\mathbf{3 4}$ and $\mathbf{3 5}$ (Scheme 14). These reactions are likely to involve the formation of intermediate $\mathbf{3 6}$, generated by trapping of an in situ formed iminium ion with the isocyanide.

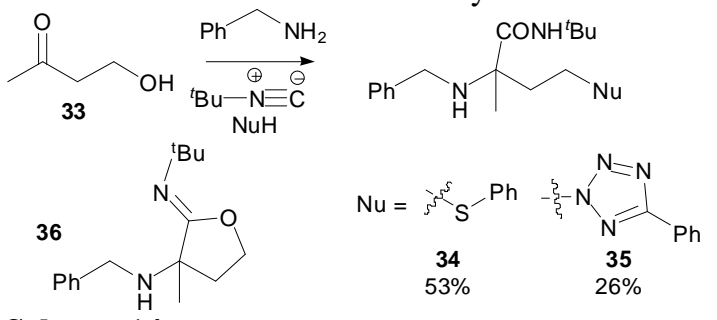

Scheme 14

\section{Conclusions.}

In summary, oxazolidines clearly constitute a powerful and flexible scaffold for a diverse set of multicomponent transformations, leading to potentially useful structural diversity in a single reaction step. A wide range of ethanolamines, carbonyl compounds, isocyanides and carboxylic acids can be employed in either three- or fourcomponent reaction sequences. These reactions can be extended to incorporate a variety of nucleophiles in place of the carboxylic acid component including thiols and tetrazoles, and the use of other $\mathrm{N}, \mathrm{O}$-acetals is also feasible. Further work is underway to explore the full scope of these novel multicomponent reactions of $\mathrm{N}, \mathrm{O}$ acetals and to extend them to other systems.

\section{Experimental.}

\subsection{General methods.}

Melting points were performed on a Reichert Thermovar hot stage apparatus and are uncorrected. Boiling points were measured during distillation. ${ }^{1} \mathrm{H}$ NMR spectra were recorded at $300 \mathrm{MHz}$ on a Bruker AMX300 spectrometer at $300 \mathrm{~K}$ and ${ }^{13} \mathrm{C}$ NMR spectra were recorded at $75 \mathrm{MHz}$ on a Bruker AMX300 spectrometer at $300 \mathrm{~K}$ unless otherwise stated. Macherey-Nagel $0.20 \mathrm{~mm}$ silica gel $60 \mathrm{UV}_{254}$ plates were used for TLC. Infrared spectra were carried out on a Shimadzu FTIR 8700 and were recorded as a thin film or a nujol ${ }^{\circledR}$ mull in between $\mathrm{NaCl}$ disks. Mass spectra and accurate mass measurements were recorded using a Micromass 70-SE magnetic sector spectrometer at the University College London Chemistry department. Unless stated, chemicals were used as purchased and without further purification. Unless otherwise stated, all reactions were performed under an atmosphere of nitrogen using oven dried glassware, which was cooled under a flow of nitrogen prior to use. DMSO was distilled from calcium hydride. Benzene was distilled from sodium benzophenone ketyl. THF, $\mathrm{CH}_{2} \mathrm{Cl}_{2}, \mathrm{Et}_{2} \mathrm{O}, \mathrm{MeCN}$, toluene and $n$-hexane, were prepared as anhydrous, degassed solvents from an anhydrous engineering $^{\circledR}$ zeolite drying apparatus. Methanol from was distilled from magnesium methoxide. Anhydrous isopropanol was purchased from Sigma Aldrich. Petrol refers to light petroleum ether bp $40-60{ }^{\circ} \mathrm{C}$.

Oxazolidines 1a-1g and 21a-21b were prepared from the corresponding carbonyl compounds and the appropriate aminoalcohol by: i. repeated concentration of an ethanol solution; ii. heating under Dean-Stark conditions in the presence of a trace amount of iodine; or iii. stirring in ether in the presence of $\mathrm{MgSO}_{4}{ }^{6,9,13} \mathrm{~N}, \mathrm{O}$-Acetals 28 and 
29 were prepared from 1,2-dihydrofuran and 1,2-dihydropyran respectively according to a literature procedure. $^{17}$ Spectroscopic data for these compounds were identical to those previously reported.

\subsubsection{General Procedure for 3-CR in MeCN (Method A)}

Oxazolidine ( $2 \mathrm{mmol})$, carboxylic acid $(2 \mathrm{mmol})$, para-toluenesulfonic acid $(38 \mathrm{mg}, 0.2 \mathrm{mmol})$ and isocyanide $(2 \mathrm{mmol})$ were added to $\mathrm{MeCN}(5 \mathrm{~mL})$ and heated at reflux under an atmosphere of nitrogen for 18-24 h until completion by TLC. Excess solvent was removed under reduced pressure and the crude product was purified by column chromatography to yield the product.

\subsubsection{Optimized general procedure for 3-CR in ${ }^{i} \mathrm{PrOH}$ (Method B)}

Oxazolidine $(2 \mathrm{mmol})$, carboxylic acid $(2 \mathrm{mmol})$, para-toluenesulfonic acid $(8 \mathrm{mg}, 0.04 \mathrm{mmol})$ and isocyanide $(2 \mathrm{mmol})$ were added to ${ }^{\mathrm{i}} \mathrm{PrOH}(2 \mathrm{~mL})$ and heated at reflux under an atmosphere of nitrogen for 18-24 h until completion by TLC. Excess solvent was removed under reduced pressure and the crude product was purified by column chromatography to yield the product.

\subsubsection{Optimized general procedure for $4-\mathrm{CR}$ in ${ }^{i} \mathrm{PrOH}$ (Method $\mathrm{C}$ )}

Aldehyde / ketone (2 mmol), aminoalcohol (2 mmol), para-toluenesulfonic acid ( $8 \mathrm{mg}, 0.04 \mathrm{mmol})$, carboxylic acid $(2 \mathrm{mmol})$, and isocyanide $(2 \mathrm{mmol})$ were added to ${ }^{i} \mathrm{PrOH}(2 \mathrm{~mL})$ and heated at reflux under an atmosphere of nitrogen for 18-24 h. Excess solvent was removed under reduced pressure and the crude product was purified by column chromatography to yield the product.

\subsubsection{2-[(tert-Butylcarbamoyl-p-tolylmethyl)methylamino]ethyl benzoate 4a.}

Yield: $66 \%$ (Method A), 68\% (Method C); Colourless oil; $R_{f}=0.23$ (Petrol:EtOAc, 2:1) IR (film) $v_{\max } 3400$ 3100 (br), 2928, 1718, 1665, 1604, 1514, $1365 \mathrm{~cm}^{-1}$. ${ }^{1} \mathrm{H}$ NMR $\left(\mathrm{CDCl}_{3}, 300 \mathrm{MHz}\right) \delta 1.27(9 \mathrm{H}, \mathrm{s}, \mathrm{t}-\mathrm{Bu}), 2.27(3 \mathrm{H}$, s, tolyl- $\left.\mathrm{CH}_{3}\right), 2.34\left(3 \mathrm{H}, \mathrm{s}, \mathrm{N}-\mathrm{CH}_{3}\right), 2.67-2.88\left(2 \mathrm{H}, \mathrm{m}, \mathrm{N}-\mathrm{CH}_{2}\right), 4.00(1 \mathrm{H}, \mathrm{s}, \mathrm{CH}), 4.33-4.65\left(2 \mathrm{H}, \mathrm{m}, \mathrm{CH}_{2}-\mathrm{O}\right), 6.93$ $(1 \mathrm{H}, \mathrm{bs}, \mathrm{NH}), 7.05-7.60(9 \mathrm{H}, \mathrm{m}, \mathrm{Ar}) ;{ }^{13} \mathrm{C} \mathrm{NMR}\left(75 \mathrm{MHz}, \mathrm{CDCl}_{3}\right) \delta 21.1,28.6,40.5,50.7,53.5,62.4,75.6$, 128.4, 129.0, 129.2, 129.7, 130.1, 132.9, 133.1, 137.8, 166.5, 170.8; HRMS (CI): $[\mathrm{M}+\mathrm{H}]^{+}, \mathrm{C}_{23} \mathrm{H}_{31} \mathrm{~N}_{2} \mathrm{O}_{3}$ requires 383.23347, found 383.23425.

\subsubsection{2-[(tert-Butylcarbamoyl-p-tolylmethyl)methylamino]ethyl propionate $4 \mathrm{~b}$.}

Yield: 64\% (Method A); Colourless oil; $\mathrm{R}_{\mathrm{f}} 0.26$ (Petrol:EtOAc, 2:1); IR (film) $v_{\max } 3404$ (br), 3054, 2970, 2926, 2826, 1737, 1664, 1513, $1456 \mathrm{~cm}^{-1}$; ${ }^{1} \mathrm{H}$ NMR $\left(\mathrm{CDCl}_{3}, 400 \mathrm{MHz}\right) \delta 1.08\left(3 \mathrm{H}, \mathrm{t}, J 7.7 \mathrm{~Hz}, \mathrm{CH}_{2}-\mathrm{C}_{3}\right), 1.28(9 \mathrm{H}, \mathrm{s}$, $t$-Bu), $2.14\left(3 \mathrm{H}, \mathrm{s}, \mathrm{Ph}-\mathrm{CH}_{3}\right), 2.25\left(3 \mathrm{H}, \mathrm{s}, \mathrm{N}-\mathrm{CH}_{3}\right), 2.27\left(2 \mathrm{H}, \mathrm{q}, J 7.7 \mathrm{~Hz}, \mathrm{CH}_{2}-\mathrm{CH}_{3}\right), 2.54\left(2 \mathrm{H}, \mathrm{t}, J 5.8 \mathrm{~Hz}, \mathrm{~N}-\mathrm{CH}_{2}\right)$, $3.76(1 \mathrm{H}, \mathrm{s}, \mathrm{CH}), 4.10\left(2 \mathrm{H}, \mathrm{t}, J 5.8 \mathrm{~Hz}, \mathrm{O}-\mathrm{CH}_{2}\right), 6.23(1 \mathrm{H}, \mathrm{bs}, \mathrm{NH}), 7.03-7.10(4 \mathrm{H}, \mathrm{m}, \mathrm{Ar}-\mathrm{H}) ;{ }^{13} \mathrm{C} \mathrm{NMR}(100$ $\left.\mathrm{MHz}, \mathrm{CDCl}_{3}\right) \delta 9.5,21.5,28.0,40.7,51.0,53.9,62.3,76.3,129.2,129.5,133.6,138.1,171.2,174.7$; HRMS: $[\mathrm{M}+\mathrm{H}]^{+}, \mathrm{C}_{19} \mathrm{H}_{31} \mathrm{~N}_{2} \mathrm{O}_{3}$ requires 335.23346, found 335.23240.

\subsubsection{2-[(Cyclohexylcarbamoyl-p-tolylmethyl)methylamino]ethyl benzoate $4 c$.}

Yield: $71 \%$ (Method A); Pale yellow oil; $R_{\mathrm{f}} 0.14$ (Petrol:EtOAc, 2:1); IR (film) $v_{\max } 3310$ (br), 2922, 2952 , $1726,1651,1562,1460 \mathrm{~cm}^{-1} ;{ }^{1} \mathrm{H}$ NMR $\left(\mathrm{CDCl}_{3}, 300 \mathrm{MHz}\right) \delta 0.95-1.81(10 \mathrm{H}, \mathrm{m}$, cyclohexyl), $2.27(3 \mathrm{H}, \mathrm{s}, \mathrm{Ar}-$ $\left.\mathrm{CH}_{3}\right), 2.29\left(3 \mathrm{H}, \mathrm{s}, \mathrm{N}-\mathrm{CH}_{3}\right), 2.67-2.81\left(2 \mathrm{H}, \mathrm{m}, \mathrm{N}-\mathrm{CH}_{2}\right), 3.60-3.78(1 \mathrm{H}, \mathrm{m}, \mathrm{C} \underline{\mathrm{H} H C O}), 4.00(1 \mathrm{H}, \mathrm{s}, \mathrm{CH}), 4.30-$ $4.43\left(2 \mathrm{H}, \mathrm{m}, \mathrm{CH}_{2}-\mathrm{O}\right), 6.93(1 \mathrm{H}, \mathrm{bs}, \mathrm{NH}), 7.03-7.54(7 \mathrm{H}, \mathrm{m}, \mathrm{Ar}), 8.00-8.05(2 \mathrm{H}, \mathrm{m}, \mathrm{Ar}) ;{ }^{13} \mathrm{C} \mathrm{NMR}(75 \mathrm{MHz}$, $\left.\mathrm{CDCl}_{3}\right) \delta 21.1,24.8,25.4,32.7,40.5,50.7,53.5,62.3,75.6,128.4,129.0,129.2,129.7,130.1,132.9,133.1$, 137.8, 166.5, 170.8; HRMS: $[\mathrm{M}+\mathrm{Na}]^{+}, \mathrm{C}_{25} \mathrm{H}_{32} \mathrm{~N}_{2} \mathrm{NaO}_{3}$ requires 431.23105, found 431.23051.

\subsubsection{2-[(Isopropylcarbamoyl-p-tolylmethyl)methylamino]ethyl benzoate 4d.}

Yield: 73\% (Method A); Colourless Oil; $\mathrm{R}_{\mathrm{f}} 0.25$ (Petrol:EtOAc, 2:1); IR (film) $v_{\max } 3420$ (br), 2985, 2968, $1739,1651,1506,1452 \mathrm{~cm}^{-1} ;{ }^{1} \mathrm{H} \mathrm{NMR}\left(\mathrm{CDCl}_{3}, 400 \mathrm{MHz}\right) \delta 1.00\left(3 \mathrm{H}, \mathrm{d}, J 6.6 \mathrm{~Hz}, \mathrm{CH}-\mathrm{C} \underline{H}_{3}\right), 1.07(3 \mathrm{H}, \mathrm{d}, J$ $\left.6.6 \mathrm{~Hz}, \mathrm{CH}-\underline{\mathrm{H}}_{3}\right), 2.28\left(3 \mathrm{H}, \mathrm{s}, \mathrm{N}-\mathrm{CH}_{3}\right.$ or $\left.\mathrm{Ph}-\mathrm{C} \underline{H}_{3}\right), 2.29\left(3 \mathrm{H}, \mathrm{s}, \mathrm{N}-\mathrm{CH}_{3}\right.$ or $\left.\mathrm{Ph}-\mathrm{C}_{3}\right), 2.63-2.70(1 \mathrm{H}, \mathrm{m}, \mathrm{N}-\mathrm{C} \underline{H} \mathrm{H})$, 2.72-2.80 (1H, m, N-CH$\underline{H}), 3.96(1 \mathrm{H}, \mathrm{s}, \mathrm{C}=\mathrm{OCH}), 3.99-4.05\left(1 \mathrm{H}, \mathrm{m}, \mathrm{C} \underline{H}-\left(\mathrm{CH}_{3}\right)_{2}\right), 4.35-4.41(1 \mathrm{H}, \mathrm{m} \mathrm{O}-\mathrm{C} \underline{H} \mathrm{H})$, 4.46-4.52 (1H, m, O-CH프), $6.91(1 \mathrm{H}, \mathrm{d}, J 8.3 \mathrm{~Hz}, \mathrm{NH}), 7.10(2 \mathrm{H}, \mathrm{d}, J 7.6 \mathrm{~Hz}, \mathrm{Ar}-\mathrm{H}), 7.16-7.20$ (2H, m, Ar-H), 7.39-7.48 (2H, m, Ar-H), 7.56-7.62 (1H, m, Ar-H), 8.04-8.09 (2H, m, Ar-H); ${ }^{13} \mathrm{C}$ NMR $\left(100 \mathrm{MHz}, \mathrm{CDCl}_{3}\right) \delta$ 21.0, 22.4, 40.4, 40.7, 53.4, 62.2, 62.3, 75.1, 128.3, 128.8, 129.1, 129.5, 130.0, 132.9, 133.0, 137.7, 166.4, 170.5; HRMS: $[\mathrm{M}+\mathrm{H}]^{+}, \mathrm{C}_{22} \mathrm{H}_{29} \mathrm{~N}_{2} \mathrm{O}_{3}$ requires 369.2178, found 369.2177.

\subsubsection{2-[(tert-Butylcarbamoylheptyl)methylamino]ethyl benzoate 4e.}

Yield: $80 \%$ (Method A), 56\% (Method C); Colourless oil; $\mathrm{R}_{\mathrm{f}} 0.34$ (Petrol:EtOAc, 2:1); IR (film) $v_{\max } 3365$ (br), 3026, 2948, 2926, 2856, 1724, 1674, 1506, $1452 \mathrm{~cm}^{-1} ;{ }^{1} \mathrm{H}$ NMR $\left(\mathrm{CDCl}_{3}, 300 \mathrm{MHz}\right) \delta 0.74(3 \mathrm{H}, \mathrm{t}, J 6.9 \mathrm{~Hz}$, $\left.\mathrm{CH}_{3}\right), 1.16\left(9 \mathrm{H}, \mathrm{s},{ }^{t} \mathrm{Bu}\right), 1.17-1.41\left(6 \mathrm{H}, \mathrm{m}, \mathrm{CH}_{2}\right) 1.44-1.59\left(2 \mathrm{H}, \mathrm{m}, \mathrm{CH}_{2}\right), 1.62-1.77\left(2 \mathrm{H}, \mathrm{m}, \mathrm{CH}_{2}\right), 2.23(3 \mathrm{H}, \mathrm{s}, \mathrm{N}-$ $\left.\mathrm{CH}_{3}\right), 2.77-2.87$ (3H, m, N-CH $\mathrm{CH}_{2}$ \&H), 4.32-4.47 (2H, m, $\left.\mathrm{CH}_{2}-\mathrm{O}\right), 6.62(1 \mathrm{H}, \mathrm{bs}, \mathrm{NH}), 7.26-7.96(5 \mathrm{H}, \mathrm{m}, \mathrm{Ph})$; ${ }^{13} \mathrm{C}$ NMR $\left(75 \mathrm{MHz}, \mathrm{CDCl}_{3}\right) \delta 14.0,22.5,27.2,27.4,28.6,29.5,31.6,38.3,50.2,53.7,62.7,68.9,128.3,129.5$, 130.0, 133.0, 166.4, 172.2; HRMS: [M+H] $]^{+}, \mathrm{C}_{22} \mathrm{H}_{37} \mathrm{~N}_{2} \mathrm{O}_{3}$ requires 377.28040, found 377.28061. 
3.1.9. 2-[(tert-Butylcarbamoylheptyl)methylamino]ethyl propionate $4 \mathrm{f}$.

Yield: 78\% (Method A); Colourless oil; $R_{\mathrm{f}} 0.21$ (Petrol:EtOAc, 2:1); IR (film) $v_{\max } 3330$ (br), 2951, 2930, 2958, 1746, 1662, 1510, $1456 \mathrm{~cm}^{-1} .{ }^{1} \mathrm{H}$ NMR $\left(\mathrm{CDCl}_{3}, 300 \mathrm{MHz}\right) \delta 0.77\left(3 \mathrm{H}, \mathrm{t}, J 6.6 \mathrm{~Hz}, \mathrm{CH}_{3}\right), 1.05(3 \mathrm{H}, \mathrm{t}, J 7.5 \mathrm{~Hz}$, propyl- $\left.\mathrm{CH}_{3}\right), 1.13-1.23\left(6 \mathrm{H}, \mathrm{m}, \mathrm{CH}_{2}\right), 1.25\left(9 \mathrm{H}, \mathrm{s},{ }^{t} \mathrm{Bu}\right), 1.39-1.54\left(2 \mathrm{H}, \mathrm{m}, \mathrm{CH}_{2}\right), 1.60-1.72\left(2 \mathrm{H}, \mathrm{m}, \mathrm{CH}_{2}\right), 2.19$ $\left(3 \mathrm{H}, \mathrm{s}, \mathrm{N}-\mathrm{CH}_{3}\right), 2.25\left(2 \mathrm{H}, \mathrm{q}, J 7.5 \mathrm{~Hz}, \mathrm{C}=\mathrm{O}-\mathrm{CH}_{2}\right), 2.53-2.71\left(2 \mathrm{H}, \mathrm{m}, \mathrm{N}-\mathrm{CH}_{2}\right), 2.77(1 \mathrm{H}, \mathrm{dd}, J 7.3 \mathrm{~Hz}, 5.3 \mathrm{~Hz}$, $\mathrm{CH}), 4.04\left(2 \mathrm{H}, \mathrm{t}, J 6.5 \mathrm{~Hz}, \mathrm{O}-\mathrm{CH}_{2}\right), 6.78(1 \mathrm{H}, \mathrm{bs}, \mathrm{NH}) ;{ }^{13} \mathrm{C} \mathrm{NMR}\left(75 \mathrm{MHz}, \mathrm{CDCl}_{3}\right) \delta 9.0,14.0,22.7,27.3$, 27.5, 28.7, 29.2, 30.0, 38.4, 51.0, 53.3, 62.0, 68.9, 172.3, 174.3; HRMS: $[\mathrm{M}+\mathrm{H}]^{+}, \mathrm{C}_{18} \mathrm{H}_{37} \mathrm{~N}_{2} \mathrm{O}_{3}$ requires 329.28040 , found 329.28191 .

\subsubsection{2-[(1-Cyclohexylcarbamoylheptyl)methylamino]ethyl benzoate 4g.}

Yield: $48 \%$ (Method A), 43\% (Method C); Colourless oil; $R_{\mathrm{f}} 0.26$ (Petrol:EtOAc, 2:1); IR (film) $v_{\max } 3400$ 3250 (br), 2930, 2955, 1717, 1647, 1510, $1452 \mathrm{~cm}^{-1} ;{ }^{1} \mathrm{H} \mathrm{NMR}\left(\mathrm{CDCl}_{3}, 300 \mathrm{MHz}\right): \delta 0.86(3 \mathrm{H}, \mathrm{t}, J 7.0 \mathrm{~Hz}$, $\left.\mathrm{CH}_{3}\right), 0.88-1.05\left(3 \mathrm{H}, \mathrm{m}\right.$, alkyl), $1.20\left(9 \mathrm{H}, \mathrm{m}\right.$, alkyl), 1.32-1.80 (8H, m, alkyl), $2.27\left(3 \mathrm{H}, \mathrm{s}, \mathrm{N}-\mathrm{CH}_{3}\right), 2.83-2.97$ $\left(3 \mathrm{H}, \mathrm{m}, \mathrm{N}-\mathrm{CH}_{2}\right.$ and $\left.\mathrm{CH}\right), 3.53-3.61(1 \mathrm{H}, \mathrm{m}, \mathrm{CH}), 4.28-4.42\left(2 \mathrm{H}, \mathrm{m}, \mathrm{CH}_{2}-\mathrm{O}\right), 6.82(1 \mathrm{H}, \mathrm{d}, \mathrm{J}=8.5 \mathrm{~Hz}, \mathrm{NH}), 7.36-$ $7.41(2 \mathrm{H}, \mathrm{m}, \mathrm{Ar}-\mathrm{H}), 7.47-7.51(1 \mathrm{H}, \mathrm{m}, \mathrm{Ar}-\mathrm{H})$ 7.96-8.01 (2H, m, Ar-H); ${ }^{13} \mathrm{C}$ NMR $\left(75 \mathrm{MHz}, \mathrm{CDCl}_{3}\right) \delta 14.0$, 22.6, 24.8, 25.4, 27.3, 27.5, 29.5, 31.7, 32.8, 33.1, 38.4, 47.5, 53.8, 62.6, 68.5, 128.4, 129.6, 130.1, 133.1, 166.5, 171.9; HRMS: $[\mathrm{M}+\mathrm{H}]^{+}, \mathrm{C}_{24} \mathrm{H}_{39} \mathrm{~N}_{2} \mathrm{O}_{3}$ requires 403.29605, found 403.29553.

\subsubsection{3-(1H-Indol-3-yl)-2-[(1-tert-butylcarbamoylheptyl)methylaminoethyl propionate $4 \mathrm{~h}$.}

Yield: 44\% (Method A); Colourless oil; $\mathrm{R}_{\mathrm{f}} 0.12$ (Petrol:EtOAc, 2:1); IR (film) $v_{\max } 3300$ (br), 3387 (br), 3020, 2959, 2930, 2858, 1732, 1666, 1514, $1456 \mathrm{~cm}^{-1}$; ${ }^{1} \mathrm{H} \mathrm{NMR}\left(\mathrm{CDCl}_{3}, 300 \mathrm{MHz}\right) \delta 0.89\left(3 \mathrm{H}, \mathrm{t}, J 6.8 \mathrm{~Hz} \mathrm{CH}_{3}\right), 1.20-$ $1.32\left(8 \mathrm{H}, \mathrm{m}, \mathrm{CH}_{2}\right), 1.37(9 \mathrm{H}, \mathrm{s}, t-\mathrm{Bu}), 1.50-1.64(1 \mathrm{H}, \mathrm{m}, \mathrm{C} \underline{H} \mathrm{H}$-alkyl), $1.68-1.82(1 \mathrm{H}, \mathrm{m}, \mathrm{CH} \underline{H}$-alkyl), $2.26(3 \mathrm{H}$, $\left.\mathrm{s}, \mathrm{N}-\mathrm{CH}_{3}\right), 2.62-2.72\left(2 \mathrm{H}, \mathrm{m}, \mathrm{N}-\mathrm{CH}_{2}\right), 2.75\left(2 \mathrm{H}, \mathrm{t}, J 7.5 \mathrm{~Hz}, \mathrm{CO}_{-} \mathrm{CH}_{2}\right), 2.87(1 \mathrm{H}, \mathrm{t}, J 5.4 \mathrm{~Hz}, \mathrm{CH}), 3.13(2 \mathrm{H}, \mathrm{t}, J$ $\left.7.5 \mathrm{~Hz}, \mathrm{C}=\mathrm{C}-\mathrm{CH}_{2}\right), 4.17\left(2 \mathrm{H}, \mathrm{t}, J 5.6 \mathrm{~Hz}, \mathrm{O}-\mathrm{CH}_{2}\right), 6.92(1 \mathrm{H}, \mathrm{s}, \mathrm{NH}), 6.97(1 \mathrm{H}, \mathrm{s}, \mathrm{C}=\mathrm{CH}), 7.11(1 \mathrm{H}, \mathrm{t}, J 7.2 \mathrm{~Hz}$, Ar), $7.18(1 \mathrm{H}, \mathrm{t}, J 7.1 \mathrm{~Hz}, \mathrm{Ar}), 7.34(1 \mathrm{H}, \mathrm{d}, J 7.8 \mathrm{~Hz}, \mathrm{Ar}), 7.69(1 \mathrm{H}, \mathrm{d}, J 7.7 \mathrm{~Hz}, \mathrm{Ar}), 8.84(1 \mathrm{H}, \mathrm{bs}, \mathrm{NH}$ indole); ${ }^{13} \mathrm{C}$ NMR $\left(75 \mathrm{MHz}, \mathrm{CDCl}_{3}\right) \delta 14.1,20.8,22.7,27.3,27.6,28.8,29.6,31.7,35.1,38.5,50.5,53.4,62.3,69.1$, 111.4, 114.3, 118.5, 119.1, 121.76, 121.82, 127.1, 136.5, 172.6, 173.5; HRMS: $[\mathrm{M}+\mathrm{H}]^{+}, \mathrm{C}_{26} \mathrm{H}_{41} \mathrm{~N}_{3} \mathrm{O}_{3}$ requires 443.31479, found 443.31388 .

\subsubsection{3-\{[1-(2,6-Dimethylphenylcarbamoyl)heptyl]methylamino\}ethyl propionate 4i.}

Yield: 42\% (Method A); Colourless oil; $\mathrm{R}_{\mathrm{f}} 0.40$ (Petrol:EtOAc, 2:1); IR (film) $v_{\max } 3300$ (br), 3020, 2955, 2928, 2856, 1738, 1674, $1468 \mathrm{~cm}^{-1} ;{ }^{1} \mathrm{H}$ NMR $\left(\mathrm{CDCl}_{3}, 300 \mathrm{MHz}\right) \delta 0.88\left(3 \mathrm{H}, \mathrm{t}, J 6.6 \mathrm{~Hz}, \mathrm{CH}_{3}\right), 1.02(3 \mathrm{H}, \mathrm{t}, J 7.5 \mathrm{~Hz}$, $\left.\mathrm{COCH}_{2} \mathrm{C}_{3}\right), 1.25-1.58\left(10 \mathrm{H}, \mathrm{m}, \mathrm{CH}_{2}\right), 1.63-1.78\left(1 \mathrm{H}, \mathrm{m}, \mathrm{CH}_{2}\right), 1.88-2.00\left(1 \mathrm{H}, \mathrm{m}, \mathrm{CH}_{2}\right), 2.21\left(6 \mathrm{H}, \mathrm{s}, \mathrm{Ar}_{-} \mathrm{CH}_{3}\right)$, $2.45\left(3 \mathrm{H}, \mathrm{s}, \mathrm{N}-\mathrm{CH}_{3}\right), 2.91\left(2 \mathrm{H}, \mathrm{m}, \mathrm{N}-\mathrm{CH}_{2},\right), 3.25(1 \mathrm{H}, \mathrm{t}, J 6.5 \mathrm{~Hz}, \mathrm{CH}), 4.22\left(2 \mathrm{H}, \mathrm{t}, J 5.5 \mathrm{~Hz}, \mathrm{CH}_{2}-\mathrm{O}\right), 7.01(3 \mathrm{H}$, s, Ar), $8.65(1 \mathrm{H}, \mathrm{bs}, \mathrm{NH}) .{ }^{13} \mathrm{C}$ NMR $\left(75 \mathrm{MHz}, \mathrm{CDCl}_{3}\right) \delta 8.9,14.1,18.7,22.6,27.33,27.38,29.6,31.7,38.8$, 54.0, 62.1, 68.6, 126.8, 128.8, 134.1, 134.9, 171.4, 174.4; HRMS: $[\mathrm{M}+\mathrm{Na}]^{+}, \mathrm{C}_{22} \mathrm{H}_{36} \mathrm{~N}_{2} \mathrm{NaO}_{3}$ requires 399.26235, found 399.26169 .

\subsubsection{2 -\{[1-(2-Chloro-6-methylphenylcarbamoyl)heptyl]methylamino\}ethyl benzoate $4 \mathbf{j}$.}

Yield: 29\% (Method A); Colourless Oil; $\mathrm{R}_{\mathrm{f}} 0.18$ (Petrol:EtOAc, 2:1); IR (film) $v_{\max } 3280$ (br), 2961, 2919, 2874, 1719, 1637, $1467 \mathrm{~cm}^{-1}$; ${ }^{1} \mathrm{H}$ NMR $\left(\mathrm{CDCl}_{3}, 400 \mathrm{MHz}\right) \delta 0.77\left(3 \mathrm{H}, \mathrm{t}, J 6.9 \mathrm{~Hz}, \mathrm{CH}_{2} \mathrm{C}_{3}\right), 1.16-1.28(6 \mathrm{H}, \mathrm{m}$, $\left.\mathrm{CH}_{2}\right), 1.32-1.47\left(2 \mathrm{H}, \mathrm{m}, \mathrm{CH}_{2}\right), 1.65-1.75\left(1 \mathrm{H}, \mathrm{CH}_{2}\right), 1.87-1.94\left(1 \mathrm{H}, \mathrm{m}, \mathrm{CH}_{2}\right), 2.10\left(3 \mathrm{H}, \mathrm{s}, \mathrm{N}-\mathrm{CH}_{3}\right), 2.55(3 \mathrm{H}, \mathrm{s}$, $\left.\mathrm{Ph}_{-} \mathrm{CH}_{3}\right), 3.13\left(2 \mathrm{H}, \mathrm{t}, J 5.6 \mathrm{~Hz}, \mathrm{~N}-\mathrm{CH}_{2}\right), 3.53(1 \mathrm{H}, \mathrm{dd}, J 7.1,6.0 \mathrm{~Hz}, \mathrm{CH}), 4.45-4.90\left(2 \mathrm{H}, \mathrm{t}, J 5.6 \mathrm{~Hz}, \mathrm{O}_{-} \mathrm{CH}_{2}\right)$, 7.05-7.32 (2H, m, Ar), 7.44-7.49 (2H, m, Ar-H), 7.57-7.61 (1H, m, Ar), 7.95-8.00 (1H, m, Ar-H), $8.11(2 \mathrm{H}, \mathrm{m}$, $\mathrm{Ar}-\mathrm{H}), 8.70(1 \mathrm{H}, \mathrm{bs}, \mathrm{NH}) ;{ }^{13} \mathrm{C}$ NMR $\left(100 \mathrm{MHz}, \mathrm{CDCl}_{3}\right) \delta 13.9,18.9,22.5,27.2,27.5,29.3,31.5,38.4,53.6$, $62.0,68.3,127.0,127.5,128.17,128.23,129.0,129.4,130.0,132.9,133.2,137.6,166.4,171.3$; HRMS: $[\mathrm{M}+\mathrm{H}]^{+}, \mathrm{C}_{25} \mathrm{H}_{34} \mathrm{ClN}_{2} \mathrm{O}_{3}$ requires 445.2258, found 445.2266.

\subsubsection{2-\{[tert-Butylcarbamoyl-(4-methoxyphenyl)methyl]methylamino\}ethyl benzoate $4 \mathbf{k}$.}

Yield: 68\% (Method A), 66\% (Method C); Colourless oil; $\mathrm{R}_{\mathrm{f}} 0.40$ (Petrol:EtOAc, 2:1); IR (film) $v_{\max } 3390$ (br), 2980, 2970, 2930, 2885, 1716, 1678, 1510, $1452 \mathrm{~cm}^{-1} ;{ }^{1} \mathrm{H} \mathrm{NMR}\left(\mathrm{CDCl}_{3}, 300 \mathrm{MHz}\right) \delta 1.27(9 \mathrm{H}, \mathrm{s}, t-\mathrm{Bu}), 2.33$ (3H, s, N-CH 3 ), 2.67-2.85 (2H, m, N-CH $), 4.02(3 \mathrm{H}, \mathrm{s}, \mathrm{OMe}), 4.06(1 \mathrm{H}, \mathrm{s}, \mathrm{CH}), 4.32-4.62\left(2 \mathrm{H}, \mathrm{m}, \mathrm{CH}_{2}-\mathrm{O}\right), 6.78$ $(2 \mathrm{H}, \mathrm{d}, J 6.8 \mathrm{~Hz}, m-\mathrm{PhOMe}), 7.04(1 \mathrm{H}, \mathrm{bs}, \mathrm{NH}), 7.17(2 \mathrm{H}, \mathrm{d}, J 6.8 \mathrm{~Hz}, \mathrm{Ar}-\mathrm{H}), 7.32-7.53(3 \mathrm{H}, \mathrm{m}, \mathrm{Ar}-\mathrm{H}), 8.00$ $(2 \mathrm{H}, \mathrm{d}, J 8.5 \mathrm{~Hz}, \mathrm{Ar}-\mathrm{H}) ;{ }^{13} \mathrm{C} \mathrm{NMR}\left(75 \mathrm{MHz}, \mathrm{CDCl}_{3}\right) \delta 28.5,40.4,50.6,53.4,55.2,62.3,75.1,113.8,128.1$, 128.4, 129.6, 130.1, 130.2, 132.5, 133.1, 159.4, 166.4, 170.9; HRMS: $[\mathrm{M}+\mathrm{H}]^{+}, \mathrm{C}_{23} \mathrm{H}_{31} \mathrm{~N}_{2} \mathrm{O}_{4}$ requires 399.22837, found 399.22720 .

\subsubsection{2-\{[tert-Butylcarbamoyl-4-nitrophenyl)methyl]methylamino\}ethyl benzoate 4l.}

Yield: 47\% (Method A), 30\% (Method C); Orange Oil; $R_{\mathrm{f}} 0.40$ (Petrol:EtOAc, 2:1); IR (film) $v_{\max } 3300$ (br), 3060, 2990, 2895, 2805, 1716, 1682, 1521, $1452 \mathrm{~cm}^{-1} ;{ }^{1} \mathrm{H}$ NMR $\left(\mathrm{CDCl}_{3}, 300 \mathrm{MHz}\right) \delta 1.26(9 \mathrm{H}, \mathrm{s}, t-\mathrm{Bu}), 2.30$ $\left(3 \mathrm{H}, \mathrm{s}, \mathrm{N}-\mathrm{CH}_{3}\right), 2.67-2.88\left(2 \mathrm{H}, \mathrm{t}, J 5.6 \mathrm{~Hz} \mathrm{~N}-\mathrm{CH}_{2}\right), 4.18(1 \mathrm{H}, \mathrm{s}, \mathrm{CH}), 4.41\left(2 \mathrm{H}, \mathrm{m}, \mathrm{CH}_{2}-\mathrm{O}\right), 6.98(1 \mathrm{H}, \mathrm{bs}, \mathrm{NH})$, 
7.39-7.47 (4H, m, Ar-H), 7.52-7.57 (1H, m, Ar-H), 8.01 (2H, d, J 8.6 Hz, Ar-H), 8.12 (2H, d, J 8.6 Hz, Ar-H); ${ }^{13} \mathrm{C} \mathrm{NMR}\left(75 \mathrm{MHz}, \mathrm{CDCl}_{3}\right) \delta 28.5,40.0,51.0,53.8,61.9,74.7,123.5,128.5,129.6,129.9,130.2,133.3,143.0$, 147.5, 166.4, 169.1; HRMS: [M+Na] ${ }^{+}, \mathrm{C}_{22} \mathrm{H}_{27} \mathrm{~N}_{3} \mathrm{NaO}_{5}$ requires 437.19099, found 437.19266.

\subsubsection{2-[Benzyl-(tert-butylcarbamoyl-p-tolylmethyl)amino]ethyl benzoate $\mathbf{4 m}$.}

Yield: 44\% (Method A); Colorless Oil; $R_{\mathrm{f}} 0.28$ (Petrol:EtOAc, 4:1); IR (film) $v_{\max } 3342$ (br), 2924, 1717, 1678, $1510,1364 \mathrm{~cm}^{-1}$; ${ }^{1} \mathrm{H}$ NMR $\left(\mathrm{CDCl}_{3}, 300 \mathrm{MHz}\right) \delta 1.26(9 \mathrm{H}, \mathrm{s}, t-\mathrm{Bu}), 2.34\left(3 \mathrm{H}, \mathrm{s}, \mathrm{Ph}-\mathrm{CH}_{3}\right), 2.79-2.98(2 \mathrm{H}, \mathrm{m}, \mathrm{N}-$ $\left.\mathrm{CH}_{2}\right), 3.53-3.58\left(1 \mathrm{H}, \mathrm{d}, J 4.7 \mathrm{~Hz}, \mathrm{Ph}-\mathrm{CH}_{2}\right), 3.87-3.92\left(1 \mathrm{H}, \mathrm{d}, \mathrm{J}=4.7 \mathrm{~Hz}\right.$, benzylic $\left.\mathrm{CH}_{2}\right), 4.20-4.49\left(2 \mathrm{H}, \mathrm{m}, \mathrm{CH}_{2}-\right.$ O), $4.39(1 \mathrm{H}, \mathrm{s}, \mathrm{CH}), 6.96(1 \mathrm{H}, \mathrm{bs}, \mathrm{NH}), 7.13-7.98(14 \mathrm{H}, \mathrm{m}, \mathrm{Ar}-\mathrm{H}) ;{ }^{13} \mathrm{C} \mathrm{NMR}\left(75 \mathrm{MHz}, \mathrm{CDCl}_{3}\right) \delta 21.2,28.7$, 49.2, 50.9, 56.3, 62.6, 70.2, 127.4, 128.4, 128.5, 129.0, 129.7, 129.9, 130.2, 132.1, 133.1, 137.6, 138.8, 166.5, 170.8; HRMS: $[\mathrm{M}+\mathrm{H}]^{+}, \mathrm{C}_{29} \mathrm{H}_{35} \mathrm{~N}_{2} \mathrm{O}_{3}$ requires 459.26475, found 459.26337.

\subsubsection{2-[(1-tert-Butylcarbamoylcyclohexyl)methylamino]ethyl benzoate $4 \mathbf{n}$.}

Yield: 63\% (Method A); Colourless Oil; $R_{\mathrm{f}} 0.63$ (Petrol:EtOAc, 2:1); IR (film) $v_{\max } 3380$ (br), 2973, 2944, 2870, 1710, 1680, 1505, $1465 \mathrm{~cm}^{-1}$; ${ }^{1} \mathrm{H}$ NMR $\left(\mathrm{CDCl}_{3}, 300 \mathrm{MHz}\right) \delta 1.19(9 \mathrm{H}, \mathrm{s}, t-\mathrm{Bu}), 1.30-1.37\left(2 \mathrm{H}, \mathrm{m}, \mathrm{CH}_{2}\right)$ 1.51-1.91 (8H, m, $\left.\mathrm{CH}_{2}\right), 2.21\left(3 \mathrm{H}, \mathrm{s}, \mathrm{N}-\mathrm{CH}_{3}\right), 2.68\left(2 \mathrm{H}, \mathrm{t}, J 6.0 \mathrm{~Hz}, \mathrm{~N}-\mathrm{CH}_{2},\right), 4.28\left(2 \mathrm{H}, \mathrm{t}, J 6.1 \mathrm{~Hz} \mathrm{CH}_{2}-\mathrm{O}\right), 6.22$ $(1 \mathrm{H}, \mathrm{bs}, \mathrm{NH}), 7.04-7.41(3 \mathrm{H}, \mathrm{m}, \mathrm{Ar}), 7.92(2 \mathrm{H}, \mathrm{d}, J 9.4 \mathrm{~Hz}, \mathrm{Ar}) ;{ }^{13} \mathrm{C}$ NMR $\left(75 \mathrm{MHz}, \mathrm{CDCl}_{3}\right) \delta 22.9,25.9,28.6$, 30.2 , 36.0, 49.8, 50.1, 63.7, 66.4, 128.3, 129.9, 130.1, 132.9, 166.3, 174.4; HRMS: $[\mathrm{M}+\mathrm{H}]^{+}, \mathrm{C}_{21} \mathrm{H}_{33} \mathrm{~N}_{2} \mathrm{O}_{3}$ requires 361.24910 , found 361.24790 .

\subsubsection{2-[tert-Butyl-(tert-butylcarbamoyl-p-tolyl-methyl)amino]ethyl acetate 40.}

Yield: $20 \%$ (Method A); Colourless needles mp 90-91 ${ }^{\circ} \mathrm{C}\left(\mathrm{CHCl}_{3}\right) ; \mathrm{R}_{\mathrm{f}} 0.40$ (Petrol:EtOAc, 2:1); IR (KBr Disc) $v_{\max } 3314$ (br), 2968, 2924, 1738, 1670, 1506, $1456 \mathrm{~cm}^{-1} ; \delta{ }^{1} \mathrm{H} \mathrm{NMR}\left(\mathrm{CDCl}_{3}, 300 \mathrm{MHz}\right) \delta 1.16(9 \mathrm{H}, \mathrm{s}, t-\mathrm{Bu})$, $1.41(9 \mathrm{H}, \mathrm{s}, t \mathrm{Bu}), 2.00\left(3 \mathrm{H}, \mathrm{s}, \mathrm{CO}_{2} \mathrm{CH}_{3}\right), 2.28\left(3 \mathrm{H}, \mathrm{s}, \mathrm{CH}_{3}\right.$ tolyl $), 2.30-2.41(1 \mathrm{H}, \mathrm{m}, \mathrm{N}-\mathrm{C} \underline{H} \mathrm{H}), 2.81-2.92(1 \mathrm{H}, \mathrm{m}$, $\mathrm{N}-\mathrm{CH} \underline{H}), 3.58-3.67(1 \mathrm{H}, \mathrm{m}, \mathrm{O}-\mathrm{C} \underline{H} \mathrm{H}), 3.78-3.87(1 \mathrm{H}, \mathrm{m}, \mathrm{O}-\mathrm{CH} \underline{H}), 4.55(1 \mathrm{H}, \mathrm{s}, \mathrm{CH}), 7.01(2 \mathrm{H}, \mathrm{d}, J 8.1 \mathrm{~Hz}, \mathrm{Ph})$, $7.08(2 \mathrm{H}, \mathrm{d}, J 8.1 \mathrm{~Hz}, \mathrm{Ph}), 7.83(1 \mathrm{H}, \mathrm{bs}, \mathrm{NH}) ;{ }^{13} \mathrm{C} \mathrm{NMR}\left(75 \mathrm{MHz}, \mathrm{CDCl}_{3}\right) \delta 21.1,27.9,28.7,42.8,50.6,56.7$, 65.2, 66.6, 129.5, 130.2, 134.4, 137.3, 170.7, 174.0; HRMS: $[\mathrm{M}+\mathrm{H}]^{+}, \mathrm{C}_{21} \mathrm{H}_{35} \mathrm{~N}_{2} \mathrm{O}_{3}$ requires 363.26475, found 363.26552.

\subsubsection{2-[(tert-Butylcarbamoyl-p-tolylmethyl)methylamino]ethyl acetate 4p.}

Yield: 54\% (Method B); Colourless Oil; $R_{\mathrm{f}} 0.40$ (2:1 Petrol:EtOAc); IR (thin film) $v_{\max } 3330$ (br), 2987, 2943, 2872, 2875, 1732, 1667, 1515, $1455 \mathrm{~cm}^{-1} ;{ }^{1} \mathrm{H} \mathrm{NMR}\left(\mathrm{CDCl}_{3}, 400 \mathrm{MHz}\right) \delta 1.28(9 \mathrm{H}, \mathrm{s}, \mathrm{t}-\mathrm{Bu}), 2.09(3 \mathrm{H}, \mathrm{s}$, $\left.\mathrm{COCH}_{3}\right), 2.16\left(3 \mathrm{H}, \mathrm{s}\right.$, tolyl- $\left.\mathrm{CH}_{3}\right), 2.23\left(3 \mathrm{H}, \mathrm{s}, \mathrm{N}-\mathrm{CH}_{3}\right), 2.54\left(2 \mathrm{H}, \mathrm{t}, J 5.6 \mathrm{~Hz}, \mathrm{~N}-\mathrm{CH}_{2}\right), 3.76(1 \mathrm{H}, \mathrm{s}, \mathrm{CH}), 4.09$ $\left(2 \mathrm{H}, \mathrm{t}, J 5.6, \mathrm{O}-\mathrm{CH}_{2}\right), 6.95(1 \mathrm{H}, \mathrm{bs}, \mathrm{NH}), 7.11(2 \mathrm{H}, \mathrm{d}, J 8.0 \mathrm{~Hz}, \mathrm{Ar}), 7.23(2 \mathrm{H}, \mathrm{d}, J 8.0 \mathrm{~Hz}, \mathrm{Ar}) ;{ }^{13} \mathrm{C} \mathrm{NMR}$ $\left(\mathrm{CDCl}_{3}, 100 \mathrm{MHz}\right) \delta 21.1,21.2,28.7,40.2,51.5,53.5,61.9,75.5,127.5,128.8,129.1,133.0,138.8,167.4$, 169.2; HRMS: $[\mathrm{M}+\mathrm{H}]^{+}, \mathrm{C}_{18} \mathrm{H}_{29} \mathrm{~N}_{2} \mathrm{O}_{3}$ requires 321.2173, found 321.2155; LRMS: $[\mathrm{M}+\mathrm{H}]^{+}, 176$ (100), 321 (78, $\mathrm{M}+\mathrm{H}), 220$ (54), 343 (17, M+Na), 177 (12), 221 (8).

\subsubsection{2-[(tert-Butylcarbamoyl-p-tolylmethyl)methylamino]ethyl acetate- ${ }^{18} \mathrm{O}_{2}{ }^{4 p-}{ }^{18} \mathrm{O}_{2}$.}

Yield: 47\% (Method B); Colourless Oil; $\mathrm{R}_{\mathrm{f}} 0.37$ (Petrol:EtOAc, 2:1); IR (film) $v_{\max } 3360$ (br), 2966, 2920, $2884,1708,1643,1512,1456 \mathrm{~cm}^{-1} ;{ }^{1} \mathrm{H}$ NMR $\left(\mathrm{CDCl}_{3}, 300 \mathrm{MHz}\right) \delta 1.28(9 \mathrm{H}, \mathrm{s}, t-\mathrm{Bu}), 2.00\left(3 \mathrm{H}, \mathrm{s}, \mathrm{COCH}_{3}\right)$, $2.15\left(3 \mathrm{H}, \mathrm{s}\right.$, tolyl- $\left.\mathrm{CH}_{3}\right), 2.24\left(3 \mathrm{H}, \mathrm{s}, \mathrm{N}-\mathrm{CH}_{3}\right), 2.57-2.62\left(2 \mathrm{H}, \mathrm{m}, \mathrm{N}-\mathrm{CH}_{2}\right), 3.83(1 \mathrm{H}, \mathrm{s}, \mathrm{CH}), 4.10(2 \mathrm{H}, \mathrm{t}, J 5.7 \mathrm{~Hz}$, $\left.\mathrm{O}-\mathrm{CH}_{2}\right), 6.99(1 \mathrm{H}, \mathrm{bs}, \mathrm{NH}), 7.04-7.23(4 \mathrm{H}, \mathrm{m}, \mathrm{Ar}-\mathrm{H}) ;{ }^{13} \mathrm{C} \mathrm{NMR}\left(75 \mathrm{MHz}, \mathrm{CDCl}_{3}\right) \delta 20.9,21.0,28.5,40.0,50.6$, 53.3, 61.6, 75.5, 128.6, 128.8, 129.0, 129.2, 137.7, 137.9, 170.3 (br), 170.7; HRMS: $[\mathrm{M}+\mathrm{H}]^{+}, \mathrm{C}_{18} \mathrm{H}_{29} \mathrm{~N}_{2} \mathrm{O}^{18} \mathrm{O}_{2}$ requires 325.22630 , found 325.22528 .

Fragmentation of the $[\mathrm{M}+\mathrm{H}]^{+}$ion, $\mathrm{m} / \mathrm{z} 321$ was achieved by in-source collision induced dissociation (CID). The in-source CID mass spectrum for the labelled compound $4 \mathbf{p}-{ }^{18} \boldsymbol{O}_{2}$ showed the fragment ion at $\mathrm{m} / \mathrm{z} 222$, consistent with $\left[\mathrm{M}+\mathrm{H}-\mathrm{C}_{4} \mathrm{H}_{9} \mathrm{NHC}^{18} \mathrm{OH}\right]^{+}$, a loss of $103 \mathrm{Da}$. The in-source CID mass spectrum for the non-labeled compound $4 \mathbf{p}$ showed the fragment ion at $\mathrm{m} / \mathrm{z} 220$, consistent with $\left[\mathrm{M}+\mathrm{H}-\mathrm{C}_{4} \mathrm{H}_{9} \mathrm{NHCOH}\right]^{+}$, a loss of $101 \mathrm{Da}$.

\subsection{Multicomponent Reaction of Acid-Aldehydes}

3.2.1. 5-Methyl-1-oxo-3,4,5,6-tetrahydro-1H-benzo[f][1,4]oxazocine-6-carboxylic acid cyclohexylamide 12 . 2-(Methylamino)-ethanol (161 $\mu \mathrm{l}, 2 \mathrm{mmol}), \mathrm{TsOH}(8 \mathrm{mg}, 0.04 \mathrm{mmol})$, and cyclohexyl isocyanide $(202 \mu \mathrm{l}, 2$ mmol) were added to a solution of 2-carboxybenzaldehyde (300 mg, $2 \mathrm{mmol})$ in anhydrous ${ }^{i} \operatorname{PrOH}(1.5 \mathrm{~mL})$. The mixture was stirred for $48 \mathrm{~h}$ at $\mathrm{rt}$ under $\mathrm{N}_{2}$. Excess solvent was removed under reduced pressure and the residue was purified by flash chromatography (2:1 Petrol:EtOAc) to give $\mathbf{1 2}$ as a white solid, which was recrystallised from methanol to give colourless needles $(202 \mathrm{mg}, 33 \%) ; \mathrm{mp} 146-148^{\circ} \mathrm{C} ; \mathrm{R}_{\mathrm{f}} 0.12(2: 1$ Petrol:EtOAc); IR (KBr Disc) $v_{\max } 3309,2936,2854,1717,1634,1539,1454 \mathrm{~cm}^{-1} .{ }^{1} \mathrm{H}$ NMR $\left(\mathrm{CDCl}_{3}\right) \delta 1.08-$ 1.37 (5H, m, cy), 1.51-1.88 (5H, m, cy), $2.32\left(3 \mathrm{H}, \mathrm{s}, \mathrm{N}-\mathrm{CH}_{3}\right), 2.94(1 \mathrm{H}, \mathrm{ddd}, J 14.2,7.3,3.8 \mathrm{~Hz}, \mathrm{~N}-\mathrm{C} \underline{H} \mathrm{H}), 3.07$ $(1 \mathrm{H}$, ddd, $J 14.2,4.0,3.8 \mathrm{~Hz}, \mathrm{~N}-\mathrm{CH} \underline{H}), 3.69(1 \mathrm{H}, \mathrm{dtd}, J 10.5,8.5,3.9 \mathrm{~Hz}, \mathrm{cy}), 3.84(1 \mathrm{H}, \mathrm{ddd}, J 12.6,5.8,3.8 \mathrm{~Hz}$, O-C $\underline{H} \mathrm{H}), 4.07(1 \mathrm{H}, \mathrm{ddd}, J 12.6,7.3,4.0 \mathrm{~Hz}, \mathrm{O}-\mathrm{CH} \underline{H}), 4.27(1 \mathrm{H}, \mathrm{s}, \mathrm{CH}), 6.96(1 \mathrm{H}, \mathrm{d}, J 8.2 \mathrm{~Hz}, \mathrm{NH}), 7.04-7.06$ 
$(1 \mathrm{H}, \mathrm{m}, \mathrm{Ar}), 7.28-7.32(3 \mathrm{H}, \mathrm{m}, \mathrm{Ar}) ;{ }^{13} \mathrm{C} \mathrm{NMR}\left(\mathrm{CDCl}_{3}\right) \delta 24.6,25.4,32.7,32.9,42.4,48.1,55.5,64.8,70.6$, 128.3, 128.6, 130.2, 130.8, 134.9, 168.3, 173.4; HRMS: $[\mathrm{M}+\mathrm{H}]^{+}, \mathrm{C}_{18} \mathrm{H}_{25} \mathrm{~N}_{2} \mathrm{O}_{3}$ requires 317.18652, found 317.18574; MS: (EI) 339 (100 M+Na), 317 (83, M+H), 340 (17), 318 (13), 202 (12), 221 (7).

3.2.2. 5-Benzyl-1-oxo-3,4,5,6-tetrahydro-1H-benzo[f][1,4]oxazocine-6-carboxylic acid tert-butylamide 13. 2-(Benzylamino)-ethanol $(284 \mu \mathrm{l}, 2 \mathrm{mmol}), \mathrm{TsOH}(8 \mathrm{mg}, 0.04 \mathrm{mmol})$, and tert-butyl isocyanide $(226 \mu \mathrm{l}, 2$ mmol) were added to a solution of 2-carboxybenzaldehyde (300 mg, $2 \mathrm{mmol})$ in anhydrous ${ }^{i} \operatorname{PrOH}(1.5 \mathrm{~mL})$. The mixture was stirred for 7 days at $\mathrm{rt}$ under $\mathrm{N}_{2}$. Excess solvent was removed in vacuo and the residue was purified by flash chromatography (3:2 Petrol:EtOAc) to give $\mathbf{1 3}$ as a pale yellow oil (179 $\mathrm{mg}, 25 \%) ; \mathrm{R}_{\mathrm{f}} 0.40$ (1:1 Petrol:EtOAc); IR (thin film) $v_{\max } 3340$ (br), 2984, 2924, 2885, 1716, 1667, 1486, $1408 \mathrm{~cm}^{-1}$; ${ }^{1} \mathrm{H}$ NMR $\left(\mathrm{CDCl}_{3}\right) \delta 1.29(9 \mathrm{H}, \mathrm{s}, t-\mathrm{Bu}), 2.82(1 \mathrm{H}, \mathrm{ddd}, J 14.2,6.2,4.2 \mathrm{~Hz}, \mathrm{~N}-\mathrm{C} \underline{H C H}), 3.19(1 \mathrm{H}, \mathrm{ddd}, J 14.2,6.7,4.8 \mathrm{~Hz}$, $\mathrm{N}-\mathrm{CH} \underline{H}), 3.78\left(2 \mathrm{H}, \mathrm{s}, \mathrm{Ar}-\mathrm{CH}_{2}\right), 3.88(1 \mathrm{H}, \mathrm{ddd}, J 12.5,6.8,4.2 \mathrm{~Hz}, \mathrm{O}-\mathrm{C} \underline{H} \mathrm{H}), 4.11(1 \mathrm{H}, \mathrm{ddd}, J$ 12.4, 6.3, $4.8 \mathrm{~Hz}$, $\mathrm{O}-\mathrm{CH} \underline{\underline{H}}), 4.41(1 \mathrm{H}, \mathrm{s}, \mathrm{CH}), 6.42(1 \mathrm{H}, \mathrm{bs}, \mathrm{NH}), 7.29-7.42(9 \mathrm{H}, \mathrm{m}, \mathrm{Ar}) ;{ }^{13} \mathrm{C} \mathrm{NMR}\left(\mathrm{CDCl}_{3}\right) \delta 28.5,51.5,51.8,56.9$, 64.9, 71.0, 127.3, 127.7, 128.4, 128.4, 128.7, 128.9, 129.1, 130.2, 130.8, 134.4, 137.5, 168.9, 173.7; HRMS (EI): $[\mathrm{M}+\mathrm{H}]^{+}, \mathrm{C}_{22} \mathrm{H}_{27} \mathrm{~N}_{2} \mathrm{O}_{3}$ requires 367.20217, found 367.20211; LRMS (EI): $389(100 \mathrm{M}+\mathrm{Na}), 367(64, \mathrm{M}+\mathrm{H}), 390$ (23), 369 (9), 368 (8), 181 (7).

\subsubsection{1-Methyl-7-oxo-6,7,9,10,11,12-hexahydro-5,8-dioxa-11-aza-benzocyclodecene-12-carboxylic acid tert-butylamide 14.}

2-(Methylamino)-ethanol (161 $\mu \mathrm{l}, 2 \mathrm{mmol}), \mathrm{TsOH}(8 \mathrm{mg}, 0.04 \mathrm{mmol})$, and tert-butyl isocyanide $(226 \mu \mathrm{l}, 2$ $\mathrm{mmol})$ were added to a solution of 2-formylphenoxyacetic acid (360 mg, $2 \mathrm{mmol})$ in anhydrous ${ }^{i} \mathrm{PrOH}(1.5 \mathrm{~mL})$. The mixture was stirred for $48 \mathrm{~h}$ at $\mathrm{rt}$. Excess solvent was removed under reduced pressure and the residue was purified by flash chromatography (1:1 Petrol:EtOAc) to give $\mathbf{1 4}$ as a white solid which was recrystallised from ${ }^{i} \mathrm{PrOH}$ to give colourless prisms (317 mg, $49 \%$ ); mp 140-143 ${ }^{\circ} \mathrm{C} ; \mathrm{R}_{\mathrm{f}} 0.20$ (1:1 Petrol:EtOAc); IR (KBr Disc) $v_{\max } 3356,2944,1742,1674,1508,1487,1448 \mathrm{~cm}^{-1}$; ${ }^{1} \mathrm{H}$ NMR $\left(\mathrm{CDCl}_{3}\right) \delta 1.30(9 \mathrm{H}, \mathrm{s}, \mathrm{t}-\mathrm{Bu}), 2.44\left(3 \mathrm{H}, \mathrm{s}, \mathrm{N}-\mathrm{CH}_{3}\right)$, $2.53(1 \mathrm{H}, \mathrm{dt}, J 15.5,2.3 \mathrm{~Hz}, \mathrm{~N}-\mathrm{C} \underline{H} \mathrm{H}), 2.71-2.82(1 \mathrm{H}, \mathrm{m}, \mathrm{N}-\mathrm{CH} \underline{H}), 4.24\left(2 \mathrm{H}, \mathrm{dd}, J 6.9,1.7 \mathrm{~Hz}, \mathrm{O}-\mathrm{CH}_{2}\right), 4.40$ $(1 \mathrm{H}, \mathrm{d}, J 13.4 \mathrm{~Hz}, \mathrm{OC} \underline{H} \mathrm{HC}=\mathrm{O}), 4.58(1 \mathrm{H}, \mathrm{d}, J 13.4 \mathrm{~Hz}, \mathrm{OCH} \underline{H C}=\mathrm{O}), 4.79(1 \mathrm{H}, \mathrm{s}, \mathrm{CH}), 6.66(1 \mathrm{H}, \mathrm{bs}, \mathrm{NH}), 6.98-$ $7.07(2 \mathrm{H}, \mathrm{m}, \mathrm{Ar}), 7.18(1 \mathrm{H}, \mathrm{td}, J 7.7,1.6 \mathrm{~Hz}, \mathrm{Ar}), 7.26(1 \mathrm{H}, \mathrm{dd}, J 7.6,1.4 \mathrm{~Hz}, \mathrm{Ar}) ;{ }^{13} \mathrm{C} \mathrm{NMR}\left(\mathrm{CDCl}_{3}\right) \delta 28.6$, $38.8,50.4,50.6,60.6,66.8,72.8,121.2,124.5,128.6,129.5,130.9,156.8,168.1,171.1$; HRMS $(\mathrm{EI}):[\mathrm{M}+\mathrm{H}]^{+}$, $\mathrm{C}_{17} \mathrm{H}_{25} \mathrm{~N}_{2} \mathrm{O}_{4}$ requires 321.18143, found 321.18214; LRMS (EI): $321(100 \mathrm{M}+\mathrm{H}), 322(18), 343(10, \mathrm{M}+\mathrm{Na}), 220$ (7), $276(5), 298(4)$

\subsection{General procedure for Morpholin-2-one synthesis}

Oxazolidine ( $2 \mathrm{mmol})$, TsOH $(419 \mathrm{mg}, 2.2 \mathrm{mmol})$ and tert-butyl isocyanide $(226 \mu \mathrm{l}, 2 \mathrm{mmol})$ were added to reagent grade DMSO $(5 \mathrm{~mL})$ and heated to $75{ }^{\circ} \mathrm{C}$ under an atmosphere of nitrogen for 24 hours. The reaction was cooled to rt and sat. $\mathrm{NaHCO}_{3 \text { (aq) }}(5 \mathrm{~mL})$ and EtOAc $(5 \mathrm{~mL})$ were added. The organic layer was separated and the aqueous layer was further extracted with EtOAc $(2 \times 5 \mathrm{~mL})$. The combined organic layers were then washed with brine $(5 \mathrm{~mL})$, dried $\left(\mathrm{MgSO}_{4}\right)$, filtered and evaporated under reduced pressure and purified by column chromatography (Petrol:EtOAc).

\subsubsection{3-Hexyl-4-methylmorpholin-2-one 5a.}

Yield: 69\%; Colourless oil; $\mathrm{R}_{\mathrm{f}} 0.25$ (2:1 Petrol:EtOAc); IR (thin film) $v_{\max } 2963,2931,2874,2867,1738,1552$ $1459 \mathrm{~cm}^{-1}$; ${ }^{1} \mathrm{H}$ NMR $\left(\mathrm{CDCl}_{3}, 300 \mathrm{MHz}\right) \delta 0.83\left(3 \mathrm{H}, \mathrm{t}, J 6.8 \mathrm{~Hz}, \mathrm{CH}_{2} C_{H_{3}}\right), 1.23-1.32(7 \mathrm{H}, \mathrm{m}$, alkyl), $1.45-1.54$ $\left(1 \mathrm{H}, \mathrm{m}\right.$, alkyl), 1.70-1.78 (1H, m, alkyl), 1.88-2.02 (1H, m, alkyl), $2.30\left(3 \mathrm{H}, \mathrm{s}, \mathrm{N}-\mathrm{CH}_{3}\right), 2.60(1 \mathrm{H}, \mathrm{ddd}, J 12.8$, 11.1, 3.3 Hz, N-CHH), $2.84(1 \mathrm{H}, \mathrm{dt}, J 9.8,2.7 \mathrm{~Hz}, \mathrm{~N}-\mathrm{CH} H), 2.99(1 \mathrm{H}, \mathrm{t}, J 4.9 \mathrm{~Hz}, \mathrm{CH}), 4.23-4.27(1 \mathrm{H}, \mathrm{ddd}, J$ $10.8,3.2,2.3 \mathrm{~Hz}, \mathrm{O}-\mathrm{C} \underline{H} \mathrm{H}), 4.38(1 \mathrm{H}, \mathrm{td}, J 10.9,3.1 \mathrm{~Hz}, \mathrm{O}-\mathrm{CH} \underline{H}) ;{ }^{13} \mathrm{C} \mathrm{NMR}\left(\mathrm{CDCl}_{3}, 75 \mathrm{MHz}\right) \delta 14.0,22.6$, 24.7, 29.3, 30.1, 31.7, 43.1, 51.1, 67.0, 67.7, 170.5; HRMS: $[\mathrm{M}+\mathrm{H}]^{+}, \mathrm{C}_{11} \mathrm{H}_{22} \mathrm{NO}_{2}$ requires 200.16505, found 200.16432 .

\subsubsection{4-(4-Benzyl)-3-p-tolyl-morpholin-2-one 5b.}

Yield: 60\%; Colourless oil; $\mathrm{R}_{\mathrm{f}} 0.45$ (2:1 Petrol:EtOAc); IR (thin film) $v_{\max } 3018,2973,1742,1512,1452 \mathrm{~cm}^{-1}$; ${ }^{1} \mathrm{H}$ NMR $\left(\mathrm{CDCl}_{3}, 400 \mathrm{MHz}\right) \delta 2.27\left(3 \mathrm{H}, \mathrm{s}, \mathrm{Ph}-\mathrm{CH}_{3}\right), 2.55(1 \mathrm{H}, \mathrm{ddd}, J 12.7,11.0,3.2 \mathrm{~Hz}, \mathrm{~N}-\mathrm{CHH}), 2.90(1 \mathrm{H}, \mathrm{dt}$, $J$ 12.7, $2.7 \mathrm{~Hz}, \mathrm{~N}-\mathrm{CH} \underline{H}), 3.08(1 \mathrm{H}, \mathrm{d}, J 13.3 \mathrm{~Hz}, \mathrm{Ph}-\mathrm{C} \underline{H} \mathrm{H}), 3.71(1 \mathrm{H}, \mathrm{d}, J 13.3 \mathrm{~Hz}, \mathrm{Ph}-\mathrm{CH} \underline{H}), 4.14(1 \mathrm{H}, \mathrm{s}, \mathrm{CH})$, $4.27(1 \mathrm{H}$, ddd, $J 10.8,3.2,2.4 \mathrm{~Hz}, \mathrm{O}-\mathrm{CH}), 4.46(1 \mathrm{H}, \mathrm{td}, J 11.0,3.2 \mathrm{~Hz}, \mathrm{O}-\mathrm{CH} H), 7.11(1 \mathrm{H}, \mathrm{m}, \mathrm{Ar}), 7.14(1 \mathrm{H}$, $\mathrm{m}, \mathrm{Ar}), 7.16-7.19(3 \mathrm{H}, \mathrm{m}, \mathrm{Ar}), 7.21-7.24(2 \mathrm{H}, \mathrm{m}, \mathrm{Ar}), 7.36-7.39(2 \mathrm{H}, \mathrm{m}, \mathrm{Ar}) ;{ }^{13} \mathrm{C} \mathrm{NMR}\left(\mathrm{CDCl}_{3}, 100 \mathrm{MHz}\right) \delta$ 21.5, 47.1, 59.2, 69.0, 70.7, 127.9, 128.7, 129.20, 129.23, 129.9, 134.9, 137.5, 138.6, 169.3; HRMS: [M+H] ${ }^{+}$, $\mathrm{C}_{18} \mathrm{H}_{20} \mathrm{NO}_{2}$ requires 282.14940, found 282.14894 .

\subsubsection{4-Methyl-3-p-tolylmorpholin-2-one 5c.}

Yield: 55\%; Colourless oil; $\mathrm{R}_{\mathrm{f}} 0.10$ (1:1 Petrol:EtOAc); IR (thin film) $v_{\max } 2951,2795,1738,1514,1456 \mathrm{~cm}^{-1}$; ${ }^{1} \mathrm{H} \mathrm{NMR}\left(\mathrm{CDCl}_{3}, 400 \mathrm{MHz}\right) \delta 2.19\left(3 \mathrm{H}, \mathrm{s}, \mathrm{Ar}-\mathrm{CH}_{3} / \mathrm{N}-\mathrm{CH}_{3}\right), 2.32\left(3 \mathrm{H}, \mathrm{s}, \mathrm{Ar}-\mathrm{CH}_{3} / \mathrm{N}_{-} \mathrm{CH}_{3}\right), 2.79-2.84(1 \mathrm{H}, \mathrm{m}, \mathrm{N}-$ $\mathrm{C} \underline{H} \mathrm{H}), 3.00(1 \mathrm{H}, \mathrm{ddd}, J 12.7,3.0,1.9 \mathrm{~Hz}, \mathrm{~N}-\mathrm{CH} \underline{H}), 3.87(1 \mathrm{H}, \mathrm{s}, \mathrm{CH}), 4.37-4.45(1 \mathrm{H}, \mathrm{ddd}, J 10.8,3.2,2.0 \mathrm{~Hz}, \mathrm{O}-$ $\mathrm{C} \underline{H} \mathrm{H}), 4.64(1 \mathrm{H}, \mathrm{td}, J 11.33 .5 \mathrm{~Hz}, \mathrm{O}-\mathrm{CH} \underline{H}), 7.15(2 \mathrm{H}, \mathrm{d}, J 8.0 \mathrm{~Hz}, \mathrm{Ar}-\mathrm{H}), 7.27(2 \mathrm{H}, \mathrm{d}, J 8.0 \mathrm{~Hz}, \mathrm{Ar}-\mathrm{H}) ;{ }^{13} \mathrm{C}$ 
NMR $\left(\mathrm{CDCl}_{3}, 100 \mathrm{MHz}\right) \delta 21.2,43.6,51.0,68.4,72.3,128.7,129.3,134.4,138.1,168.9 ;$ HRMS: $[\mathrm{M}+\mathrm{H}]^{+}$, $\mathrm{C}_{12} \mathrm{H}_{16} \mathrm{NO}_{2}$ requires 206.11810, found 206.11854.

\section{4. (Z)-(2,6-Dimethylphenyl)-(3-heptyl-4-methylmorpholin-2-ylidene)amine 20.}

2-Hexyl-3-methyloxazolidine $\mathbf{1 b}(342 \mathrm{mg}, 2 \mathrm{mmol})$, TsOH $(8 \mathrm{mg}, 0.04 \mathrm{mmol})$, and 2,6-dimethylphenyl isocyanide $(262 \mathrm{mg}, 2 \mathrm{mmol})$ were added to anhydrous ${ }^{i} \operatorname{PrOH}(2 \mathrm{~mL})$ and heated at reflux under an atmosphere of nitrogen for 17 hours. Excess solvent was removed under reduced pressure and the crude product was purified by column chromatography (10:1 Petrol:EtOAc) to yield $\mathbf{2 0}$ as a colourless oil ( $421 \mathrm{mg}, 73 \%$ ); $\mathrm{R}_{\mathrm{f}} 0.23$ (6:1 Petrol:EtOAc); IR (thin film) $v_{\max } 3021,2957,2957,2854,1624,1477,1443 \mathrm{~cm}^{-1} ;{ }^{1} \mathrm{H}$ NMR $\left(\mathrm{CDCl}_{3}, 300\right.$ MHz) $\delta 0.99\left(3 \mathrm{H}, \mathrm{t}, J 6.4 \mathrm{~Hz}, \mathrm{CH}_{2} \mathrm{CH}_{3}\right), 1.33-1.51(6 \mathrm{H}, \mathrm{m}$, alkyl $), 1.58-1.74(2 \mathrm{H}, \mathrm{m}$, alkyl $), 1.93-2.04(1 \mathrm{H}, \mathrm{m}$, alkyl), $2.17\left(6 \mathrm{H}, \mathrm{s}, \mathrm{Ph}-\left(\mathrm{CH}_{3}\right)_{2}\right), 2.21-2.34\left(1 \mathrm{H}, \mathrm{m}\right.$, alkyl), $2.48\left(3 \mathrm{H}, \mathrm{s}, \mathrm{N}-\mathrm{CH}_{3}\right), 2.65(1 \mathrm{H}$, ddd, $J 12.8,9.4,3.8 \mathrm{~Hz}$, $\mathrm{N}-\mathrm{C} \underline{H} \mathrm{H}), 2.92(1 \mathrm{H}, \mathrm{dt}, J 12.8,3.5 \mathrm{~Hz}, \mathrm{~N}-\mathrm{CH} \underline{H}), 3.32(1 \mathrm{H}, \mathrm{t}, J 4.8 \mathrm{~Hz}, \mathrm{CH}), 4.05-4.22\left(2 \mathrm{H}, \mathrm{m}, \mathrm{O}-\mathrm{CH}_{2}\right), 6.83(1 \mathrm{H}$, t, $J 7.6 \mathrm{~Hz}, \mathrm{Ar}-\mathrm{H}), 7.04(2 \mathrm{H}, \mathrm{d}, J 7.6 \mathrm{~Hz}, \mathrm{Ar}-\mathrm{H}) ;{ }^{13} \mathrm{C} \mathrm{NMR}\left(\mathrm{CDCl}_{3}, 75 \mathrm{MHz}\right) \delta 14.2,18.9,22.7,25.4,29.7,31.8$, 32.0, 43.5, 51.1, 65.2, 66.4, 122.6, 127.5, 128.3, 145.4, 155.8; HRMS (CI): $[\mathrm{M}+\mathrm{H}]^{+}, \mathrm{C}_{19} \mathrm{H}_{31} \mathrm{~N}_{2} \mathrm{O}$ requires 303.24364, found 303.24371.

\subsection{General procedure for reaction of $N$-unsubstituted oxazolidines to give 22a-22d}

Oxazolidine 21 ( $2 \mathrm{mmol})$, benzoic acid $(2 \mathrm{mmol})$ and tert-butyl isocyanide $(2 \mathrm{mmol})$ were added to anhydrous ${ }^{i} \mathrm{PrOH}(2 \mathrm{~mL})$ and heated at reflux under an atmosphere of nitrogen for $18 \mathrm{~h}$. Excess solvent was removed under reduced pressure and the crude product was purified by column chromatography (4:1 Petrol:EtOAc) to yield the ester 22.

\subsubsection{2-[(tert-Butylcarbamoyl-p-tolylmethyl)amino]ethyl benzoate 22a.}

Yield: $90 \% ; \mathrm{R}_{\mathrm{f}}=0.36$ (2:1 Petrol:EtOAc); Colourless oil $(516 \mathrm{mg}, 70 \%)$. $\mathrm{R}_{\mathrm{f}} 0.36$ (2:1 Petrol:EtOAc); IR (thin film) $v_{\max } 3370(\mathrm{br}), 2985,2930,2880,1716,1670,1514,1452 \mathrm{~cm}^{-1} ;{ }^{1} \mathrm{H}$ NMR $\left(\mathrm{CDCl}_{3}\right) \delta 1.28(9 \mathrm{H}, \mathrm{s}, t-\mathrm{Bu}), 2.07$ $(1 \mathrm{H}, \mathrm{bs}, \mathrm{NH}), 2.28\left(3 \mathrm{H}, \mathrm{s}\right.$, tolyl- $\left.\mathrm{CH}_{3}\right), 2.88-3.02\left(2 \mathrm{H}, \mathrm{m}, \mathrm{N}-\mathrm{CH}_{2}\right), 4.08(1 \mathrm{H}, \mathrm{s}, \mathrm{CH}), 4.34-4.41\left(2 \mathrm{H}, \mathrm{m}, \mathrm{O}-\mathrm{CH}_{2}\right)$, $6.96(1 \mathrm{H}, \mathrm{s}, \mathrm{NH}), 7.10(2 \mathrm{H}, \mathrm{d}, J 7.8 \mathrm{~Hz}, \mathrm{Ar}), 7.22(2 \mathrm{H}, \mathrm{d}, J 8.1 \mathrm{~Hz}, \mathrm{Ar}), 7.38-7.55(3 \mathrm{H}, \mathrm{m}, \mathrm{Ar}), 8.00(2 \mathrm{H}, \mathrm{d}, J 8.3$ $\mathrm{Hz}, \mathrm{Ar}) ;{ }^{13} \mathrm{C}$ NMR $\left(\mathrm{CDCl}_{3}\right) \delta 21.1,28.7,47.1,50.6,64.3,67.7,126.8,128.4,129.1,129.5,130.0,133.1,136.6$, 137.7, 166.5, 171.2; HRMS (FAB): $[\mathrm{M}+\mathrm{H}]^{+}, \mathrm{C}_{22} \mathrm{H}_{29} \mathrm{~N}_{2} \mathrm{O}_{3}$ requires 369.21781, found 369.21690; LRMS (FAB): 369 (100, M+H), 268 (61), 370 (27), 154 (23), 176 (13).

\subsubsection{2-(1-(tert-Butylamino)-2-methyl-1-oxopropan-2-ylamino)ethyl 3-(1H-indol-3-yl)propanoate 22b.}

Yield: $38 \%$; Colourless prisms, mp $112-114{ }^{\circ} \mathrm{C}\left({ }^{i} \mathrm{PrOH}\right) ; \mathrm{R}_{\mathrm{f}} 0.11$ (Petrol:EtOAc/Et $\left.3 \mathrm{~N}, 50: 50: 1\right)$; IR (KBr Disc)

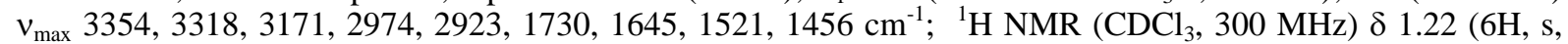
$\left.\left(\mathrm{CH}_{3}\right)_{2}\right), 1.27(9 \mathrm{H}, \mathrm{s}, t-\mathrm{Bu}), 2.04(1 \mathrm{H}, \mathrm{s}, \mathrm{NH}), 2.67\left(2 \mathrm{H}, \mathrm{t}, J 5.5 \mathrm{~Hz}, \mathrm{~N}-\mathrm{CH}_{2}\right), 2.75\left(2 \mathrm{H}, \mathrm{t}, J 7.5 \mathrm{~Hz}, \mathrm{CO}-\mathrm{CH}_{2}\right), 3.12$ $\left(2 \mathrm{H}, \mathrm{t}, J 7.5 \mathrm{~Hz}\right.$, Indole- $\left.\mathrm{CH}_{2}\right), 3.61-4.36\left(2 \mathrm{H}, \mathrm{m}, \mathrm{O}-\mathrm{CH}_{2}\right), 7.00(1 \mathrm{H}, \mathrm{d}, J 2.2 \mathrm{~Hz}, \mathrm{Ar}-\mathrm{H}), 7.11-7.22(2 \mathrm{H}, \mathrm{m}, \mathrm{Ar}-$ H), $7.28(1 \mathrm{H}, \mathrm{bs}, \mathrm{NH}$ amide), $7.34(1 \mathrm{H}, \mathrm{d}, J 8.0 \mathrm{~Hz}, \mathrm{Ar}-\mathrm{H}), 7.59(1 \mathrm{H}, \mathrm{d}, J 7.7 \mathrm{~Hz}, \mathrm{Ar}-\mathrm{H}), 8.51(1 \mathrm{H}, \mathrm{bs}, \mathrm{NH}$ indole); ${ }^{13} \mathrm{C} \mathrm{NMR}\left(\mathrm{CDCl}_{3}, 75 \mathrm{MHz}\right) \delta 20.7,25.5,28.7,34.9,42.3,50.1,58.8,64.5,111.3,114.5,118.6,119.2$, 121.6, 122.0, 127.1, 136.4, 173.4, 175.6; HRMS (CI): $[\mathrm{M}+\mathrm{H}]^{+}, \mathrm{C}_{21} \mathrm{H}_{32} \mathrm{~N}_{3} \mathrm{O}_{3}$ requires 374.24437, found 374.24483 .

\subsubsection{2-(1-Cyclohexylcarbamoyl-1-methylethylamino)ethyl benzoate 22c.}

Yield: 37\%; Yellow oil; $\mathrm{R}_{\mathrm{f}} 0.19$ (Et $2 \mathrm{O}$ ); IR (thin film) $v_{\max } 3320$ (br), 2930, 2871, 1720, 1661, 1514, $1463 \mathrm{~cm}^{-1}$; ${ }^{1} \mathrm{H}$ NMR $\left(\mathrm{CDCl}_{3}, 300 \mathrm{MHz}\right) \delta$ 0.83-1.04 (4H, m, Cy), $1.27\left(6 \mathrm{H}, \mathrm{s},\left(\mathrm{CH}_{3}\right)_{2}\right), 1.44-1.61(4 \mathrm{H}, \mathrm{m}, \mathrm{Cy}), 1.70-1.79$ $(2 \mathrm{H}, \mathrm{m}, \mathrm{Cy}), 2.83\left(2 \mathrm{H}, \mathrm{t}, J 5.4 \mathrm{~Hz}, \mathrm{~N}-\mathrm{CH}_{2}\right), 3.56-3.64(1 \mathrm{H}, \mathrm{tdt}, J 10.6,8.9,3.9 \mathrm{~Hz} \mathrm{C} H \mathrm{NHCO}), 4.35(2 \mathrm{H}, \mathrm{t}, J 5.4$ $\left.\mathrm{Hz}, \mathrm{O}-\mathrm{CH}_{2}\right), 7.21(1 \mathrm{H}, \mathrm{bd}, J 8.4 \mathrm{~Hz}, \mathrm{CONH}), 7.41(2 \mathrm{H}, \mathrm{dd}, J 8.5,7.4 \mathrm{~Hz}, \mathrm{Ar}-\mathrm{H}), 7.53(1 \mathrm{H}, \mathrm{tt}, J 7.4,1.3 \mathrm{~Hz}, \mathrm{Ar}-$ $\mathrm{H}), 8.00(2 \mathrm{H}$, br d, $J 8.5 \mathrm{~Hz}, \mathrm{Ar}-\mathrm{H}) ;{ }^{13} \mathrm{C}$ NMR $\left(\mathrm{CDCl}_{3}, 75 \mathrm{MHz}\right) \delta 24.8,25.5,25.7,33.0,42.7,47.5,58.5,64.9$, 128.4, 129.6, 130.0, 133.1, 166.5, 175.2; HRMS: $[\mathrm{M}+\mathrm{H}]^{+}, \mathrm{C}_{19} \mathrm{H}_{29} \mathrm{~N}_{2} \mathrm{O}_{3}$ requires 333.21782, found 333.21810.

\subsubsection{2-(1-tert-Butylcarbamoyl-1-methylethylamino)ethyl benzoate 22d.}

Yield: Colourless oil $\left(224 \mathrm{mg}, 37 \%\right.$ ). $\mathrm{R}_{\mathrm{f}} 0.35$ (1:1 Petrol:EtOAc); IR (thin film) $v_{\max } 3330$ (br), 2995, 2940, $2880,1720,1665,1510,1406 \mathrm{~cm}^{-1} ;{ }^{1} \mathrm{H}$ NMR $\left(\mathrm{CDCl}_{3}\right) \delta 1.27(9 \mathrm{H}, \mathrm{s}, t-\mathrm{Bu}), 1.28\left(6 \mathrm{H}, \mathrm{s}, 2 \times \mathrm{CH}_{3}\right), 2.86(2 \mathrm{H}, \mathrm{t}, J$ $\left.5.5 \mathrm{~Hz}, \mathrm{~N}-\mathrm{CH}_{2}\right), 4.37\left(2 \mathrm{H}, \mathrm{t}, J 5.6 \mathrm{~Hz}, \mathrm{O}-\mathrm{CH}_{2}\right), 7.13(1 \mathrm{H}, \mathrm{bs}, \mathrm{NH}), 7.43(2 \mathrm{H}, \mathrm{t}, J 7.5 \mathrm{~Hz}, m-\mathrm{Ar}), 7.52(1 \mathrm{H}, \mathrm{m}, p-$ $\mathrm{Ar}), 8.01(2 \mathrm{H}, \mathrm{d}, J 7.5 \mathrm{~Hz}, o-\mathrm{Ar}) ;{ }^{13} \mathrm{C}$ NMR $\left(\mathrm{CDCl}_{3}\right) \delta 25.6,28.6,42.6,50.1,58.9,65.0,128.4,129.6,130.0$, 133.1, 166.6, 175.6; HRMS (CI ): $[\mathrm{M}+\mathrm{H}]^{+}, \mathrm{C}_{17} \mathrm{H}_{27} \mathrm{~N}_{2} \mathrm{O}_{3}$ requires 307.20216, found 307.20284; LRMS (CI): 206 (100), 307 (63, M+H), 111 (16), 149 (15), 113 (15), 207 (14).

\subsection{5. $N$-(tert-Butylcarbamoyl-p-tolylmethyl)- $N$-(2-hydroxyethyl)benzamide 23 .}

2-p-Tolyl-oxazolidine 21a ( $327 \mathrm{mg}, 2 \mathrm{mmol}$ ), benzoic acid ( $244 \mathrm{mg}, 2 \mathrm{mmol})$, and tert-butyl isocyanide ( $226 \mu \mathrm{l}$, $2 \mathrm{mmol}$ ) were added to anhydrous methanol $(5 \mathrm{~mL})$ at room temperature and stirred for $42 \mathrm{~h}$ under an atmosphere of nitrogen. Excess solvent was removed under reduced pressure and the crude product was purified by column chromatography (2:1 Petrol:EtOAc) to yield $\mathbf{2 3}(660 \mathrm{mg}, 90 \%)$ as colourless needles; $\mathrm{R}_{\mathrm{f}} 0.16$ (2:1 Petrol:EtOAc); mp 138-139 ${ }^{\circ} \mathrm{C}$ ('PrOH /Petrol); IR (KBr Disc) v $v_{\max } 3406$ (br), 3317, 3027, 2993, 2981, 2931, 
$1665,1618,1542,1450,1419 \mathrm{~cm}^{-1} ;{ }^{1} \mathrm{H}$ NMR (DMSO- $\left.d_{6}, 400 \mathrm{MHz}, 373 \mathrm{~K}\right) \delta 1.35(9 \mathrm{H}, \mathrm{s}, t-\mathrm{Bu}), 2.33(3 \mathrm{H}, \mathrm{s}, \mathrm{Ph}-$ $\left.\mathrm{CH}_{3}\right), 3.13-3.27\left(2 \mathrm{H}, \mathrm{m}, \mathrm{N}-\mathrm{CH}_{2}\right), 3.39-3.49\left(2 \mathrm{H}, \mathrm{m}, \mathrm{O}-\mathrm{CH}_{2}\right), 4.45(1 \mathrm{H}, \mathrm{bs}, \mathrm{OH}), 5.58(1 \mathrm{H}, \mathrm{s}, \mathrm{CH}), 7.20-7.26$ $(4 \mathrm{H}, \mathrm{m}, \mathrm{Ar}-\mathrm{H}), 7.38(1 \mathrm{H}, \mathrm{bs}, \mathrm{NH}), 7.43-7.48(5 \mathrm{H}, \mathrm{m}, \mathrm{Ar}-\mathrm{H}) ;{ }^{13} \mathrm{C}$ NMR $\left(100 \mathrm{MHz}, \mathrm{DMSO}-d_{6}, 373 \mathrm{~K}\right) \delta 19.9$, 27.9, 47.5, 50.1, 58.6, 63.9, 125.9, 127.6, 128.34, 128.40, 128.5, 132.9, 136.6, 136.7, 168.5, 171.5; HRMS: $[\mathrm{M}+\mathrm{H}]^{+}, \mathrm{C}_{22} \mathrm{H}_{29} \mathrm{~N}_{2} \mathrm{O}_{3}$ requires 369.21782, found 369.21828 .

\subsection{Incorporation of Other Nucleophilic Components}

3.6.1. $S$ - $\{2-[($ tert-Butylcarbamoyl-p-tolylmethyl)methylamino]ethyl $\}$ thiobenzoate 24 .

Oxazolidine 1a $(355 \mathrm{mg}, 2 \mathrm{mmol})$, thiobenzoic acid $(259 \mu \mathrm{l}, 2 \mathrm{mmol})$, TsOH $(38 \mathrm{mg}, 0.2 \mathrm{mmol})$ and tert-butyl isocyanide (166 mg, $226 \mu \mathrm{l}, 2 \mathrm{mmol})$ were added to $\mathrm{MeCN}(5 \mathrm{~mL})$ and heated at reflux under an atmosphere of argon for $24 \mathrm{~h}$. Excess solvent was removed under reduced pressure and the crude product was purified by column chromatography (4:1 Petrol:EtOAc) to yield 24 as a pale yellow oil; $\mathrm{R}_{\mathrm{f}} 0.33$ (Petrol:EtOAc, 2:1); IR (thin film) $v_{\max } 3444$ (br), 3007, 2970, 2898, 1667, 1662, 1506, 1470; ${ }^{1} \mathrm{H}$ NMR $\left(\mathrm{CDCl}_{3}, 400 \mathrm{MHz}\right) \delta 1.24(9 \mathrm{H}, \mathrm{s}$, $t$-Bu), $2.15\left(3 \mathrm{H}, \mathrm{s}, \mathrm{N}-\mathrm{CH}_{3}\right), 2.22\left(3 \mathrm{H}, \mathrm{s}, \mathrm{Ar}-\mathrm{CH}_{3}\right), 3.02\left(2 \mathrm{H}, \mathrm{t}, J 6.7 \mathrm{~Hz}, \mathrm{~N}-\mathrm{CH}_{2}\right), 3.09-3.21\left(2 \mathrm{H}, \mathrm{m}, \mathrm{S}-\mathrm{CH}_{2}\right), 3.81$ $(1 \mathrm{H}, \mathrm{bs}, \mathrm{CH}), 7.02(2 \mathrm{H}, \mathrm{d}, J 8.0 \mathrm{~Hz}, \mathrm{Ar}-\mathrm{H}), 7.09(2 \mathrm{H}, \mathrm{d}, J 8.0 \mathrm{~Hz}, \mathrm{Ar}-\mathrm{H}), 7.34-7.38$ (2H, m, Ar-H), 7.47-7.51 $(1 \mathrm{H}, \mathrm{m}, \mathrm{Ar}-\mathrm{H}), 7.87-7.89(2 \mathrm{H}, \mathrm{m}, \mathrm{Ar}-\mathrm{H}) ;{ }^{13} \mathrm{C}$ NMR $\left(100 \mathrm{MHz}, \mathrm{CDCl}_{3}\right) \delta 21.5,27.6,29.0,39.9,51.0,54.5,75.5$, 127.1, 128.5, 128.9, 130.0, 132.8, 133.4, 136.8, 137.5, 170.5, 191.2; HRMS: $[\mathrm{M}+\mathrm{H}]^{+}, \mathrm{C}_{23} \mathrm{H}_{31} \mathrm{~N}_{2} \mathrm{O}_{2} \mathrm{~S}$ requires 399.2106 , found 399.2109 .

\subsubsection{2-[Methyl-(2-phenylsulfanylethyl)amino]octanoic acid tert-butylamide 25a.}

Oxazolidine 1 b $(342 \mathrm{mg}, 2 \mathrm{mmol})$, thiophenol $(205 \mu \mathrm{l}, 2 \mathrm{mmol})$, TsOH $(19 \mathrm{mg}, 0.1 \mathrm{mmol})$ and tert-butyl isocyanide (166 mg, $226 \mu \mathrm{l}, 2 \mathrm{mmol})$ were added to anhydrous MeCN (1 mL) and heated at reflux under an atmosphere of nitrogen for $24 \mathrm{~h}$. Excess solvent was removed under reduced pressure and the crude product was purified by column chromatography (8:1 Petrol:EtOAc) to yield 25a as a colourless oil (428 mg, $59 \%) ; \mathrm{R}_{\mathrm{f}} 0.21$ (6:1 Petrol:EtOAc); IR (thin film) $v_{\max } 3430$ (br), 2958, 2927, 2856, 1674, 1510, 1481, $1456 \mathrm{~cm}^{-1}$; ${ }^{1} \mathrm{H} \mathrm{NMR}$ $\left(\mathrm{CDCl}_{3}, 300 \mathrm{MHz}\right) \delta 0.81\left(3 \mathrm{H}, \mathrm{t}, J 6.7 \mathrm{~Hz}, \mathrm{CH}_{2} \mathrm{C}_{3}\right), 1.21(7 \mathrm{H}, \mathrm{bs}$, alkyl), $1.28(9 \mathrm{H}, \mathrm{s}, t-\mathrm{Bu}), 1.34-1.59(2 \mathrm{H}, \mathrm{m}$, alkyl), 1.64-1.73 (1H, m, alkyl), $2.19\left(3 \mathrm{H}, \mathrm{s}, \mathrm{N}-\mathrm{CH}_{3}\right), 2.71\left(2 \mathrm{H}, \mathrm{t}, J 6.6 \mathrm{~Hz}, \mathrm{~N}-\mathrm{CH}_{2}\right), 2.81(1 \mathrm{H}, \mathrm{dd}, J 5.5,7.1 \mathrm{~Hz}$, $\mathrm{CH}), 2.99\left(2 \mathrm{H}, \mathrm{t}, J 6.6 \mathrm{~Hz}, \mathrm{~S}-\mathrm{CH}_{2}\right), 7.10-7.29(5 \mathrm{H}, \mathrm{m}, \mathrm{Ph}) ;{ }^{13} \mathrm{C} \mathrm{NMR}\left(\mathrm{CDCl}_{3}, 75 \mathrm{MHz}\right) \delta 14.1,22.6,27.2,27.5$, $28.7,29.2,31.7,32.7,37.4,50.4,53.7,68.7,126.0,128.9,129.2,136.4,172.4 ;$ HRMS: $[\mathrm{M}+\mathrm{H}]^{+}, \mathrm{C}_{21} \mathrm{H}_{37} \mathrm{~N}_{2} \mathrm{OS}$ requires 365.26265 , found 365.26202 .

\subsubsection{1-[Methyl(2-phenylsulfanylethyl)amino]cyclohexanecarboxylic acid tert-butylamide 25 b.}

Oxazolidine 1f $(311 \mathrm{mg}, 2 \mathrm{mmol})$, thiophenol $(205 \mu \mathrm{l}, 2 \mathrm{mmol})$, TsOH $(19 \mathrm{mg}, 0.1 \mathrm{mmol})$ and tert-butyl isocyanide $(166 \mathrm{mg}, 226 \mu \mathrm{l}, 2 \mathrm{mmol})$ were added to anhydrous MeCN (1 mL) and heated at reflux under an atmosphere of nitrogen for $24 \mathrm{~h}$. Excess solvent was removed under reduced pressure and the crude product was purified by column chromatography (6:1 Petrol:EtOAc) to yield $\mathbf{2 5 b}$ as a colourless oil (154 mg, $22 \%$ ); $\mathrm{R}_{\mathrm{f}} 0.4$ (6:1 Petrol:EtOAc); IR (thin film) $v_{\max } 3450$ (br), 2959, 2931, 2873, 2860, 1728, $1464 \mathrm{~cm}^{-1}$; ${ }^{1} \mathrm{H} \mathrm{NMR}\left(\mathrm{CDCl}{ }_{3}\right.$, $300 \mathrm{MHz}) \delta 1.32(9 \mathrm{H}, \mathrm{s}, t-\mathrm{Bu}), 1.39-1.77(10 \mathrm{H}, \mathrm{m}, \mathrm{cy}), 2.23\left(3 \mathrm{H}, \mathrm{s}, \mathrm{N}-\mathrm{CH}_{3}\right), 2.70\left(2 \mathrm{H}\right.$, br t, $\left.J 7.0 \mathrm{~Hz}, \mathrm{~N}-\mathrm{CH}_{2}\right)$, $3.03\left(2 \mathrm{H}\right.$, br t, $\left.J 7.0 \mathrm{~Hz}, \mathrm{~S}-\mathrm{CH}_{2}\right), 6.71(1 \mathrm{H}, \mathrm{bs}, \mathrm{NH}), 7.14-7.34(5 \mathrm{H}, \mathrm{m}, \mathrm{Ar}-\mathrm{H}) ;{ }^{13} \mathrm{C} \mathrm{NMR}\left(\mathrm{CDCl}_{3}, 75 \mathrm{MHz}\right) \delta$ 23.0, 26.0, 28.7, 30.3, 33.5, 34.5, 66.6, 125.9, 128.9, 129.0, 136.8, 175.6; HRMS: $[\mathrm{M}+\mathrm{H}]^{+}, \mathrm{C}_{20} \mathrm{H}_{33} \mathrm{~N}_{2} \mathrm{OS}$ requires 349.23135 , found 349.23170 .

\subsection{4. $N$-tert-Butyl-2-(2-phenylsulfanylethylamino)-2-p-tolylacetamide 25 c.}

Oxazolidine 22a $(163 \mathrm{mg}, 2 \mathrm{mmol})$, thiophenol $(205 \mu \mathrm{l}, 2 \mathrm{mmol})$, TsOH $(8 \mathrm{mg}, 0.02 \mathrm{mmol})$ and tert-butyl isocyanide (166 mg, $226 \mu \mathrm{l}, 2 \mathrm{mmol})$ were added to anhydrous MeCN (2 mL) and heated at reflux under an atmosphere of nitrogen for $24 \mathrm{~h}$. Excess solvent was removed under reduced pressure and the crude product was purified by column chromatography $(2: 1$ Petrol:EtOAc) to yield $25 \mathrm{c}$ as a colourless oil (40 mg, $6 \%) ; \mathrm{R}_{\mathrm{f}} 0.19$ (2:1 Petrol:EtOAc); IR (thin film) $v_{\max } 3330$ (br), 2974, 2905, 2865, 1662, 1515, 1480, $1454 \mathrm{~cm}^{-1}$; ${ }^{1} \mathrm{H}$ NMR $\left(\mathrm{CDCl}_{3}, 300 \mathrm{MHz}\right) \delta 1.32(9 \mathrm{H}, \mathrm{s}, t-\mathrm{Bu}), 1.91-2.04(1 \mathrm{H}, \mathrm{bs}, \mathrm{NH}), 2.37\left(3 \mathrm{H}, \mathrm{s}, \mathrm{Ar}-\mathrm{CH}_{3}\right), 2.84\left(2 \mathrm{H}, \mathrm{m}, \mathrm{S}-\mathrm{CH}_{2}\right)$, 3.02-3.08 $\left(2 \mathrm{H}, \mathrm{m}, \mathrm{NH}-\mathrm{CH}_{2}\right), 3.97(1 \mathrm{H}, \mathrm{s}, \mathrm{CH}), 7.13-7.37(9 \mathrm{H}, \mathrm{m}, \mathrm{Ar}-\mathrm{H}) ;{ }^{13} \mathrm{C} \mathrm{NMR}\left(75 \mathrm{MHz}, \mathrm{CDCl}_{3}\right) \delta 21.2$, 28.7, 34.5, 47.2, 50.7, 67.7, 126.4, 127.0, 129.0, 129.5, 129.7, 131.8, 136.7, 137.6, 171.2; HRMS: $[\mathrm{M}+\mathrm{H}]^{+}$, $\mathrm{C}_{21} \mathrm{H}_{29} \mathrm{~N}_{2} \mathrm{OS}$ requires 357.20006, found 357.20142.

3.6.5. 2-\{Methyl[2-(5-phenyltetrazol-1-yl)ethyl]amino\}octanoic acid tert-butylamide 26 .

Oxazolidine 1b (343 mg, $2 \mathrm{mmol})$, 5-phenyl-1ㅡ-tetrazole (292 mg, $2 \mathrm{mmol})$, TsOH (19 mg, $0.1 \mathrm{mmol})$ and tertbutyl isocyanide $(226 \mu \mathrm{l}, 2 \mathrm{mmol})$ were added to anhydrous MeCN $(5 \mathrm{~mL})$ at $\mathrm{rt}$ and then heated at reflux under an atmosphere of nitrogen for $24 \mathrm{~h}$. Excess solvent was removed under reduced pressure and the crude product was purified by column chromatography (80:10:1 Petrol:EtOAc:Et $\left.{ }_{3} \mathrm{~N}\right)$ to yield 26a as a colourless oil $(565 \mathrm{mg}$, $71 \%$ ); $\mathrm{R}_{\mathrm{f}} 0.35$ ( 90:30:1 Petrol:EtOAc:Et ${ }_{3} \mathrm{~N}$ ); IR (thin film) $v_{\max } 3335$ (br), 2955, 2920, 2862, 1665, 1518, 1460 $\mathrm{cm}^{-1} ;{ }^{1} \mathrm{H}$ NMR $\left(\mathrm{CDCl}_{3}\right) \delta 0.74\left(3 \mathrm{H}, \mathrm{t}, J 6.8 \mathrm{~Hz}, \mathrm{CH}_{2} \mathrm{C}_{3}\right), 1.11(9 \mathrm{H}, \mathrm{s}, \mathrm{t}-\mathrm{Bu}), 1.16-1.28(8 \mathrm{H}, \mathrm{m}$, alkyl), 1.33-1.44 $(1 \mathrm{H}, \mathrm{m}$, alkyl $), 1.57-1.68(1 \mathrm{H}, \mathrm{m}$, alkyl $), 2.17\left(3 \mathrm{H}, \mathrm{s}, \mathrm{N}-\mathrm{CH}_{3}\right), 2.76(1 \mathrm{H}, \mathrm{dd}, J 7.1,5.8 \mathrm{~Hz}, \mathrm{CH}), 3.03(1 \mathrm{H}, \mathrm{ddd}, J$ 13.6, 7.0, 5.2 Hz, $\left.\mathrm{CH}_{3} \mathrm{NCHH}\right), 3.13\left(1 \mathrm{H}\right.$, ddd, $J$ 13.6, 7.0, 5.2 Hz, $\left.\mathrm{CH}_{3} \mathrm{NCH} H\right), 4.58(1 \mathrm{H}$, ddd, $J$ 13.9, 7.0, 5.2 $\mathrm{Hz}, \mathrm{N}-\mathrm{C} \underline{H} \mathrm{H}), 4.67(1 \mathrm{H}, \mathrm{ddd}, J 13.9,7.0,5.1 \mathrm{~Hz}, \mathrm{~N}-\mathrm{CH} \underline{H}), 6.26(1 \mathrm{H}, \mathrm{s}, \mathrm{NH}), 7.31-7.39$ (3H, m, Ar), 8.00-8.05 $(2 \mathrm{H}, \mathrm{m}, \mathrm{Ar}) ;{ }^{13} \mathrm{C} \mathrm{NMR}\left(\mathrm{CDCl}_{3}\right) \delta 14.0,22.5,27.0,27.4,28.5,29.2,31.6,37.3,50.3,51.3,53.9,68.6,126.7$, 
127.3, 128.8, 130.3, 165.0, 171.6; HRMS (CI): $[\mathrm{M}+\mathrm{H}]^{+}, \mathrm{C}_{22} \mathrm{H}_{37} \mathrm{~N}_{6} \mathrm{O}$ requires 401.30287, found 401.30378; LRMS (CI): 401 (100, M+H), 300 (80), 104 (53), 402 (26), 255 (23), 272 (20).

3.6.6. $N$-tert-Butyl-2-(methyl(2-(5-phenyl-2H-tetrazol-2-yl)ethyl)amino)-2-p-tolylacetamide $26 \mathrm{~b}$.

Oxazolidine 1a (355 mg, $2 \mathrm{mmol})$, 5-phenyl-1H-tetrazole (292 mg, $2 \mathrm{mmol})$, TsOH (19 mg, $0.1 \mathrm{mmol})$ and tertbutyl isocyanide $(226 \mu \mathrm{l}, 2 \mathrm{mmol})$ were added to anhydrous $\mathrm{MeCN}(5 \mathrm{~mL})$ at $\mathrm{rt}$ and then heated at reflux under an atmosphere of nitrogen for $24 \mathrm{~h}$. Excess solvent was removed under reduced pressure and the crude product was purified by column chromatography (80:10:1 Petrol:EtOAc: $\left.\mathrm{Et}_{3} \mathrm{~N}\right)$ to yield 26b as a colourless oil (441 mg, $67 \%$ ); $\mathrm{R}_{\mathrm{f}} 0.11$ 90:30:1 (Petrol:EtOAc:Et 3 N); IR (thin film) $v_{\max } 3190$ (br), 2966, 2873, 1668, 1514, 1466, 1452 $\mathrm{cm}^{-1} ;{ }^{1} \mathrm{H} \mathrm{NMR}\left(\mathrm{CDCl}_{3}\right) \delta 1.56(9 \mathrm{H}, \mathrm{s}, \mathrm{t}-\mathrm{Bu}), 2.26\left(3 \mathrm{H}, \mathrm{s}, \mathrm{N}-\mathrm{CH}_{3}\right), 2.33\left(3 \mathrm{H}, \mathrm{s}\right.$, tolyl- $\left.\mathrm{CH}_{3}\right), 2.85-2.92(1 \mathrm{H}, \mathrm{m}$, $\left.\mathrm{CH}_{3} \mathrm{NC} \underline{H} \mathrm{H}\right), 2.99\left(1 \mathrm{H}, \mathrm{m}, \mathrm{CH}_{3} \mathrm{NCH} \underline{H}\right), 3.84(1 \mathrm{H}, \mathrm{s}, \mathrm{CH}), 4.62-4.68(1 \mathrm{H}, \mathrm{m}, \mathrm{N}-\mathrm{C} \underline{H} \mathrm{H}), 4.72-4.81(1 \mathrm{H}, \mathrm{m}, \mathrm{N}-$ $\mathrm{CH} \underline{H}), 6.61(1 \mathrm{H}, \mathrm{s}, \mathrm{NH}), 6.92(2 \mathrm{H}, \mathrm{d}, J 8.2 \mathrm{~Hz}, \mathrm{Ar}), 7.02(2 \mathrm{H}, \mathrm{d}, J 7.8 \mathrm{~Hz}, \mathrm{Ar}), 7.49-7.60$ (3H, m, Ar), 8.13$8.16(2 \mathrm{H}, \mathrm{m}, \mathrm{Ar}) ;{ }^{13} \mathrm{C} \mathrm{NMR}\left(\mathrm{CDCl}_{3}\right) \delta 21.1,28.5,40.1,50.7,51.1,53.1,75.4,126.8,127.4,128.8,128.9,129.3$, 130.4, 132.6, 137.9, 165.2, 170.3; HRMS $\left(\mathrm{ES}^{+}\right)$: $[\mathrm{M}+\mathrm{H}]^{+}, \mathrm{C}_{23} \mathrm{H}_{31} \mathrm{~N}_{6} \mathrm{O}$ requires 407.25593, found 407.25580; LRMS (ES): 407 (100, M+H), 429 (39, M+Na), 408 (26), 430 (8), 379 (7).

3.6.7. $N$-tert-Butyl-5-(5-phenyl-2H-tetrazol-2-yl)-2-(pyrrolidin-1-yl) pentanamide 29a and $N$-tert-butyl-5(5-phenyl-1H-tetrazol-1-yl)-2-(pyrrolidin-1-yl) pentanamide 29b, (15:1 Mixture).

1-(Tetrahydrofuran-2-yl)pyrrolidine 27 (282 mg, $2 \mathrm{mmol}), 5$-phenyl-1H-tetrazole (292 mg, $2 \mathrm{mmol}), \mathrm{TsOH}(8$ $\mathrm{mg}, 0.04 \mathrm{mmol})$ and tert-butyl isocyanide $(226 \mu \mathrm{l}, 2 \mathrm{mmol})$ were added to anhydrous $\mathrm{MeCN}(2 \mathrm{~mL})$ and heated at reflux for $42 \mathrm{~h}$ under an atmosphere of $\mathrm{N}_{2}$. Excess solvent was removed under reduced pressure and the residue was purified by flash column chromatography (2:1 Petrol:EtOAc) to give 29a and 29b (15:1 mixture) as a colourless oil (548 mg, 74\%). $\mathrm{R}_{\mathrm{f}} 0.23$ (2:1 Petrol:EtOAc); IR (thin film) $v_{\max } 3335$ (br), 2964, 2888, 1663, 1520, 1464, $1450 \mathrm{~cm}^{-1} ; 29 \mathrm{a}:{ }^{1} \mathrm{H}$ NMR $\left(\mathrm{CDCl}_{3}, 500 \mathrm{MHz}\right) \delta 1.28(9 \mathrm{H}, \mathrm{s}, \mathrm{t}-\mathrm{Bu}), 1.48-1.57(1 \mathrm{H}, \mathrm{m}, \mathrm{CHCH})$, 1.65-1.69 (4H, m, $\left.\mathrm{CH}_{2}-\mathrm{CH}_{2}\right), 1.69-1.77(1 \mathrm{H}, \mathrm{m}, \mathrm{CHCH} \underline{H}), 2.01-2.08(1 \mathrm{H}, \mathrm{m}, \mathrm{C} \underline{H} \mathrm{H}), 2.08-2.18(1 \mathrm{H}, \mathrm{m}, \mathrm{CH} \underline{H})$, 2.38-2.44 (4H, m, $\left.\mathrm{CH}_{2}-\mathrm{N}-\mathrm{CH}_{2}\right), 2.62(1 \mathrm{H}, \mathrm{dd}, J$ 8.7, $4.3 \mathrm{~Hz}, \mathrm{CH}), 4.60(1 \mathrm{H}, \mathrm{ddd}, J 13.6,8.2,6.9 \mathrm{~Hz}, \mathrm{~N}-\mathrm{C} \underline{H} \mathrm{H})$, $4.64(1 \mathrm{H}$, ddd, $J 13.6,8.2,6.9, \mathrm{~Hz}, \mathrm{~N}-\mathrm{CH} \underline{H}), 6.54(1 \mathrm{H}, \mathrm{bs}, \mathrm{NH}), 7.38-7.42(3 \mathrm{H}, \mathrm{m}, \mathrm{Ar}), 8.06(2 \mathrm{H}, \mathrm{dd}, J 8.2,1.9$ $\mathrm{Hz}, \mathrm{Ar}) ; 29 \mathrm{~b}:{ }^{1} \mathrm{H} \mathrm{NMR}\left(\mathrm{CDCl}_{3}, 500 \mathrm{MHz}\right) \delta 1.24(9 \mathrm{H}, \mathrm{s}, \mathrm{t}-\mathrm{Bu}), 1.48-1.57\left(1 \mathrm{H}, \mathrm{m}, \mathrm{CH} \underline{H} \mathrm{CH}_{2} \mathrm{~N}\right), 1.65-1.69(4 \mathrm{H}$, $\left.\mathrm{m}, \mathrm{CH}_{2}-\mathrm{CH}_{2}\right), 1.69-1.77(1 \mathrm{H}, \mathrm{m}, \mathrm{CHC} \underline{H} \mathrm{H}), 2.01-2.08(1 \mathrm{H}, \mathrm{m}, \underline{\mathrm{C}} \underline{H} \mathrm{H}), 2.08-2.18(1 \mathrm{H}, \mathrm{m}, \mathrm{CH} \underline{H}), 2.38-2.44(4 \mathrm{H}$, m, $\left.\mathrm{CH}_{2}-\mathrm{N}-\mathrm{CH}_{2}\right), 2.52(1 \mathrm{H}, \mathrm{dd}, J 8.8,4.5 \mathrm{~Hz}, \mathrm{CH}), 4.38-4.43\left(2 \mathrm{H}, \mathrm{m}, \mathrm{N}-\mathrm{CH}_{2}\right), 6.52(1 \mathrm{H}, \mathrm{bs}, \mathrm{NH}), 7.46-7.50(3 \mathrm{H}$, m, Ar), 7.61-7.65 (2H, m, Ar); 29a: ${ }^{13} \mathrm{C}$ NMR $\left(\mathrm{CDCl}_{3}, 125 \mathrm{MHz}\right) \delta 23.06,25.3,28.46,28.53,51.3,52.7,60.13$,

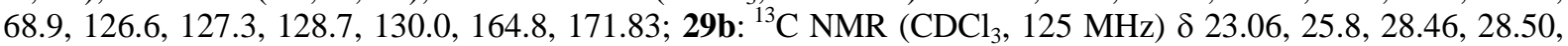
47.6, 51.2, 60.13, 68.7, 123.8, 128.5, 129.1, 131.1, 154.1, 171.72; HRMS (CI): $[\mathrm{M}+\mathrm{H}]^{+}, \mathrm{C}_{20} \mathrm{H}_{31} \mathrm{~N}_{6} \mathrm{O}$ requires 371.25592, found 371.25524; LRMS (CI): 270 (100, M+H), 371 (88, M+H), 104 (64), 225 (41), 173 (27), 189 (25).

3.6.8. $N$-tert-Butyl-2-morpholino-6-(5-phenyl-2H-tetrazol-2-yl)hexanamide 30a (major) and $N$-tert-butyl2-morpholino-6-(5-phenyl-1H-tetrazol-1-yl)hexanamide 30b (minor), (10:1 Mixture).

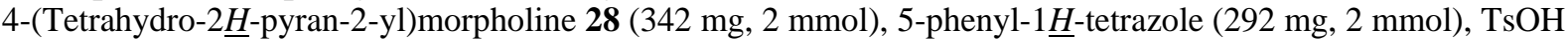
$(8 \mathrm{mg}, 0.04 \mathrm{mmol})$ and tert-butyl isocyanide $(226 \mu \mathrm{l}, 2 \mathrm{mmol})$ were added to anhydrous $\mathrm{MeCN}(2 \mathrm{~mL})$ and heated at reflux for $18 \mathrm{~h}$ under an atmosphere of $\mathrm{N}_{2}$. Excess solvent was removed under reduced pressure and the residue was purified by flash column chromatography (90:10:1 Petrol:EtOAc:Et $\left.{ }_{3} \mathrm{~N}\right)$ to give 30a and 30b (10:1 Mixture) as a colourless oil (663 mg, 83\%); $\mathrm{R}_{\mathrm{f}}$ 0.44 (90:10:1 Petrol:EtOAc:Et $\left.{ }_{3} \mathrm{~N}\right)$; IR (thin film) $v_{\max } 3320$ (br), 2963, 2952, 2863, 1663, 1533, 1464, $1452 \mathrm{~cm}^{-1} . \mathbf{3 0 a}:{ }^{1} \mathrm{H}$ NMR $\left(\mathrm{CDCl}_{3}\right) \delta 1.16(9 \mathrm{H}, \mathrm{s}, \mathrm{t}-\mathrm{Bu}), 1.22-1.1 .37$ $\left(2 \mathrm{H}, \mathrm{m}, \mathrm{CH}_{2}\right), 1.39-1.48\left(2 \mathrm{H}, \mathrm{m}, \mathrm{CHCH}_{2}\right), 1.78-1.86\left(2 \mathrm{H}, \mathrm{m}, \mathrm{CH}_{2}\right), 2.27-2.41\left(4 \mathrm{H}, \mathrm{m}, \mathrm{CH}_{2}-\mathrm{N}_{-} \mathrm{CH}_{2}\right), 2.55(1 \mathrm{H}, \mathrm{t}$, $J 6.7 \mathrm{~Hz}, \mathrm{CH}), 3.55\left(4 \mathrm{H}, \mathrm{t}, J 4.8 \mathrm{~Hz}, \mathrm{CH}_{2}-\mathrm{O}-\mathrm{CH}_{2}\right), 4.26\left(2 \mathrm{H}, \mathrm{t}, J 7.2 \mathrm{~Hz}, \mathrm{~N}-\mathrm{CH}_{2}\right), 6.62(1 \mathrm{H}, \mathrm{bs}, \mathrm{NH}), 7.38-7.42$ $(3 \mathrm{H}, \mathrm{m}, \mathrm{Ar}), 7.49-7.54(2 \mathrm{H}, \mathrm{m}, \mathrm{Ar}) .30 \mathrm{~b}:{ }^{1} \mathrm{H}$ NMR $\left(\mathrm{CDCl}_{3}\right) \delta 1.17(9 \mathrm{H}, \mathrm{s}, \mathrm{t}-\mathrm{Bu}), 1.22-1.1 .37\left(2 \mathrm{H}, \mathrm{m}, \mathrm{CH}_{2}\right), 1.50-$ $1.59\left(2 \mathrm{H}, \mathrm{m}, \mathrm{CHC} \underline{H}_{2}\right), 1.88-2.00\left(2 \mathrm{H}, \mathrm{m}, \mathrm{CH}_{2}\right), 2.27-2.41\left(4 \mathrm{H}, \mathrm{m}, \mathrm{CH}_{2}-\mathrm{N}_{-} \mathrm{CH}_{2}\right), 2.55(1 \mathrm{H}, \mathrm{t}, J 6.7 \mathrm{~Hz}, \mathrm{CH}), 3.55$ $\left(4 \mathrm{H}, \mathrm{t}, J 4.8 \mathrm{~Hz}, \mathrm{CH}_{2}-\mathrm{O}-\mathrm{CH}_{2}\right), 4.50\left(2 \mathrm{H}, \mathrm{t}, J 7.0 \mathrm{~Hz}, \mathrm{~N}-\mathrm{CH}_{2}\right), 6.61(1 \mathrm{H}, \mathrm{bs}, \mathrm{NH}), 7.28-7.37$ (3H, m, Ar), 7.96$7.99(2 \mathrm{H}, \mathrm{m}, \mathrm{Ar}) .30 \mathrm{a}:{ }^{13} \mathrm{C} \mathrm{NMR}\left(\mathrm{CDCl}_{3},\right) \delta 23.2,27.2,28.6,29.3,50.54,52.7,67.06,69.5,126.6,127.4,128.8$, 130.1, 164.8, 171.2; 30b: ${ }^{13} \mathrm{C}$ NMR $\left(\mathrm{CDCl}_{3}\right) \delta 23.4,27.0,28.6,29.5,47.7,50.54,67.06,69.3,123.8,128.6$, 129.2, 131.1, 154.2, 170.9; HRMS (FAB): $[\mathrm{M}+\mathrm{H}]^{+}, \mathrm{C}_{21} \mathrm{H}_{33} \mathrm{~N}_{6} \mathrm{O}_{2}$ requires 401.26649, found 401.26566; LRMS (FAB): 154 (100), 401 (62, M+H), 155 (24), 153 (15), 307 (14), 402 (13).

3.6.9. $N$-tert-Butyl-2-methyl-2-phenylamino-4-phenylsulfanylbutyramide 34 .

4-Hydroxybutanone $(172 \mu \mathrm{l}, 2 \mathrm{mmol})$, benzylamine $(219 \mu \mathrm{l}, 2 \mathrm{mmol})$, thiophenol $(205 \mu \mathrm{l}, 2 \mathrm{mmol})$, TsOH (4 $\mathrm{mg}, 0.02 \mathrm{mmol})$ and tert-butyl isocyanide $(226 \mu \mathrm{l}, 2 \mathrm{mmol})$ were added to anhydrous $\mathrm{MeCN}(5 \mathrm{~mL})$ and heated at $45{ }^{\circ} \mathrm{C}$ for $18 \mathrm{~h}$ under an atmosphere of $\mathrm{N}_{2}$. Excess solvent was removed under reduced pressure and the residue was purified by flash column chromatography (7:1 Petrol:EtOAc) to give 34 (373 $\mathrm{mg}, 53 \%)$ as a pale yellow oil $\mathrm{R}_{\mathrm{f}} 0.32$ (2:1 Petrol:EtOAc); IR (thin film) $v_{\max } 3345$ (br), 3012, 2998, 2887, 2952, 2913, 1668, 1583, 1480, $1439 \mathrm{~cm}^{-1} ;{ }^{1} \mathrm{H}$ NMR $\left(\mathrm{CDCl}_{3}\right) \delta 1.34(9 \mathrm{H}, \mathrm{s}, \mathrm{t}-\mathrm{Bu}), 1.37\left(3 \mathrm{H}, \mathrm{s}, \mathrm{CH}_{3}\right), 1.97-2.04\left(2 \mathrm{H}, \mathrm{m}, \mathrm{CH}_{2}\right), 2.14(1 \mathrm{H}, \mathrm{s}$, $\mathrm{NH}), 2.91(1 \mathrm{H}, \mathrm{ddd}, J 13.1,9.9,6.4 \mathrm{~Hz}, \mathrm{~S}-\mathrm{C} \underline{H} \mathrm{H}), 2.98(1 \mathrm{H}, \mathrm{ddd}, J 13.1,9.9,6.7 \mathrm{~Hz}, \mathrm{~S}-\mathrm{CH} \underline{H}), 3.53(1 \mathrm{H}, \mathrm{d}, J 12.6$ $\mathrm{Hz}, \operatorname{ArC} \underline{H} \mathrm{H}), 3.68(1 \mathrm{H}, \mathrm{d}, J 12.6 \mathrm{~Hz}, \mathrm{Ar}-\mathrm{CH} \underline{H}), 7.13(1 \mathrm{H}, \mathrm{tt}, J 6.2,1.5 \mathrm{~Hz}, \mathrm{Ar}), 7.25-7.39(10 \mathrm{H}, \mathrm{m}, \mathrm{Ar}+\mathrm{NH})$; 
${ }^{13} \mathrm{C} \mathrm{NMR}\left(\mathrm{CDCl}_{3}\right) \delta 22.5,28.6,28.8,38.6,47.5,50.4,62.0,126.1,127.3,127.9,128.7,129.0,129.1,129.2$, 136.2, 140.0, 174.0; HRMS (EI): $[\mathrm{M}+\mathrm{H}]^{+}, \mathrm{C}_{22} \mathrm{H}_{31} \mathrm{~N}_{2} \mathrm{OS}$ requires 371.21571, found 371.21583; LRMS (EI): 371 (100 M+H), 372 (22), 393 (20, M+Na), 212 (8), 270 (6), 395 (5).

3.6.10. 2-(Benzylamino)-N-tert-butyl-2-methyl-4-(5-phenyl-2H-tetrazol-2-yl)butanamide 35.

4-Hydroxybutanone (172 $\mu \mathrm{l}, 2 \mathrm{mmol})$, benzylamine $(219 \mu \mathrm{l}, 2 \mathrm{mmol}), 5$-phenyl- $1 \mathrm{H}$-tetrazole $(292 \mathrm{mg}, 2 \mathrm{mmol})$, TsOH (4 mg, $0.02 \mathrm{mmol})$ and tert-butyl isocyanide $(226 \mu \mathrm{l}, 2 \mathrm{mmol})$ were added to ${ }^{i} \mathrm{PrOH}(5 \mathrm{~mL})$ and heated at $45^{\circ} \mathrm{C}$ for $18 \mathrm{~h}$ under an atmosphere of $\mathrm{N}_{2}$. Excess solvent was removed under reduced pressure and the residue was purified by flash column chromatography (4:1 Petrol:EtOAc) to give $\mathbf{3 5}$ as a colourless oil (211 mg, $26 \%$ ) $\mathrm{R}_{\mathrm{f}} 0.36$ (2:1 Petrol:EtOAc); IR (thin film) $v_{\max } 3370$ (br), 3048, 3007, 2953, 2937, 2867, 1661, 1516, 1451,1362 $\mathrm{cm}^{-1} ;{ }^{1} \mathrm{H}$ NMR $\left(\mathrm{CDCl}_{3}\right) \delta 1.38(9 \mathrm{H}, \mathrm{s}, t-\mathrm{Bu}), 1.46\left(3 \mathrm{H}, \mathrm{s}, \mathrm{CH}_{3}\right), 2.41(1 \mathrm{H}, \mathrm{ddd}, J 14.2,8.7,6.2 \mathrm{~Hz}, \mathrm{C} \underline{H} \mathrm{H}), 2.50$ (1H, ddd, $J 14.2,8.5,7.0 \mathrm{~Hz}, \mathrm{CH} \underline{H}), 3.55(1 \mathrm{H}, \mathrm{d}, J 12.7 \mathrm{~Hz}, \mathrm{Ar}-\mathrm{C} \underline{H} \mathrm{H}), 3.68(1 \mathrm{H}, \mathrm{d}, J 12.7 \mathrm{~Hz}, \mathrm{Ar}-\mathrm{CH} \underline{H}), 4.70$ $(1 \mathrm{H}$, ddd, $J 13.8$ 8.6, $6.2 \mathrm{~Hz}, \mathrm{~N}-\mathrm{C} \underline{\mathrm{H}} \mathrm{H}), 4.87(1 \mathrm{H}, \mathrm{ddd}, J 13.8,8.7,7.0 \mathrm{~Hz}, \mathrm{~N}-\mathrm{CH} \underline{H}), 7.19-7.25(5 \mathrm{H}, \mathrm{m}, \mathrm{Ar}), 7.41$ $(1 \mathrm{H}, \mathrm{bs}, \mathrm{NH}), 7.44-7.49(3 \mathrm{H}, \mathrm{m}, \mathrm{Ar}), 8.06-8.14(2 \mathrm{H}, \mathrm{m}, \mathrm{Ar}),{ }^{13} \mathrm{C} \mathrm{NMR}\left(\mathrm{CDCl}_{3}\right) \delta 23.1,28.7,37.7,47.5,49.6$, 50.7, 61.4, 126.8, 127.3, 127.4, 127.7, 128.6, 128.9, 130.3, 139.5, 165.1, 173.4; HRMS (EI): [M+H] ${ }^{+}$, $\mathrm{C}_{23} \mathrm{H}_{30} \mathrm{~N}_{6} \mathrm{O}$ requires 407.25593, found 407.25612; LRMS (EI): 407 (100 M+H), 360 (92), 338 (54), 429 (30), $317(27), 261(22)$

1. Multicomponent Reactions; Zhu, J.; Bienaymé, H., Ed.; Wiley-VCH: Weinheim, 2005.

2. Ugi, I. Angew. Chem., Int. Ed. 1962, 1, 8.

3. Passerini, M. Gazz. Chim. Ital. 1921, 51, 126; Passerini, M. Gazz. Chim. Ital. 1931, 61, 964.

4. Ito, Y.; Imai, H.; Segoe, K.; Saegusa, T. Chem. Lett. 1984, 937; Pellissier, H.; Meou, A.; Gil, G. Tetrahedron Lett. 1986, 27, 2979; Pellissier, H.; Gil, G. Tetrahedron Lett. 1988, 29, 6773; Yoshioka, S.; Oshita, M.; Tobisui, M.; Chatani, N. Org. Lett. 2005, 7, 3697; Tobisu, M.; Kitakima, A.; Yoshioka, S.; Hyodo, I.; Oshita, M.; Chatani, N. J. Am. Chem. Soc. 2007, 129, 11431.

5. Giovenzana, G. B.; Tron, G. C.; Di Paola, S.; Menegotto, I. G.; Pirali, T. Angew. Chem. Int. Ed. 2006, 45, 1099; Pirali, T.; Callipari, G.; Ercolano, E.; Genazzani, A. A.; Giovenzana, G. B.; Tron, G. C. Org. Lett. 2008, 10, 4199.

6. Diorazio, L. J.; Motherwell, W. B.; Sheppard, T. D.; Waller, R. W. Synlett 2006, 2281.

7. Kim, Y. B.; Choi, E. H.; Keum, G.; Kang, S. B.; Lee, D. H.; Koh, H. Y.; Kim, Y. Org. Lett. 2001, 3, 4149; Banfi, L.; Basso, A.; Guanti, G.; Lecinska, P.; Riva, R. Mol. Diversity 2008, 12, 187; Mossetti, R.; Pirali, T.; Tron, G. C. J. Org. Chem. 2009, 74, 4890.

8. Armstrong, R. W.; Combs, A. P.; Tempest, P. A.; Brown, S. D.; Keating, T. A. Acc. Chem. Res. 1996, 29 , 123; Bienaymé, H.; Hulme, C.; Oddon, G.; Schmitt, P. Chem. Eur. J. 2000, 6, 3321; Dömling, A; Ugi, I, Angew. Chem. Int. Ed. 2000, 39, 3169; Dömling, A. Curr. Opin. Chem. Bio. 2002, 6, 306; Nair, V; Rajesh, C.; Vinod, A. U.; Bindu, S.; Sreekanth, A. R.; Mathen, J. S.; Balagopal, L. Acc. Chem. Res. 2003, 36, 899; Zhu, J. Eur. J. Org. Chem. 2003, 1133; Ugi, I.; Werner, B.; Dömling, A. Molecules 2003, 8, 53; Dömling, A. Chem. Rev. 2006, 106, 17; El Kaïm, L.; Grimaud, L. Tetrahedron 2009, 65, 2153. Banfi, L.; Riva, R.; Basso, A. Synlett 2010, 23.

9. Bergmann, E. J. Am. Chem. Soc. 1951, 73, 5662; Laurent, P. A.; de Almeida, R. C. F. Bull. Soc. Chim. Fr. 1967, 570; Shimizu, K.; Ito, K.; Skiya, M. Chem. Pharm. Bull. 1974, 22, 1256; Northrop, R. C.; Russ, P. L. J. Org. Chem. 1975, 40, 558; Saba, S.; Domkowski, P. W.; Firooznia, F. Synthesis 1990, 921; Tararov, V. I.; Kadyrov, R.; Riermeier, T. H.; Boerner, A. Synthesis 2002, 375.

10. For previous example of nucleophilic ring opening of cyclic iminoethers with thiols/thiobenzoic acid see: Fry, E. P. J. Org. Chem. 1950, 15, 438; Wehrmeister, H. L. J. Org. Chem. 1963, 28, 2587; Wehrmeister, H. L. J. Org. Chem. 1963, 28, 2589.

11. Carlson, R.; Carlson, J. E. Design and Optimisation in Organic Synthesis, 2nd Ed; Elsevier: Amsterdam, 2005.

12. Zhang, Z.; Jacobson, A.; Rusche, J. R.; Herlihy, W. J. Org. Chem. 1999, 64, 1074.

13. Fife, T. H.; Hagopian, L. J. Am. Chem. Soc. 1968, 90, 1007; Saavedra, J. E. J. Org. Chem. 1985, 50, 2379. 
14. Ley, S. V.; Taylor, S. J. Bioorg. Med. Chem. Lett. 2002, 12, 1813; Liu, L.; Li, C. P.; Siska, F.; Vito, F. Bioorg. Med. Chem. Lett. 2004, 14, 2221; Banfi, L.; Basso, A.; Guanti, G.; Lecinska, P.; Riva, R. Org. Biomol. Chem. 2006, 4, 4236; Banfi, L.; Basso, A.; Guanti, G.; Kielland, N.; Repetto, C.; Riva, R. J. Org. Chem. 2007, 72, 2151.

15. Heck, S.; Dömling. A. Synlett 2000, 3, 424.

16. El Kaïm, L.; Grimaud, L.; Oble, J. Angew. Chem. Int. Ed. 2005, 44, 7961; El Kaïm, L.; Gizolme, M.; Grimaud, L.; Oble, J. Org. Lett. 2006, 8, 4019; El Kaïm, L.; Gizolme, M.; Grimaud, L.; Oble, J. Synlett 2007, 465; El Kaïm, L.; Gizolme, M.; Grimaud, L.; Oble, J. J. Org. Chem. 2007, 72, 4169; Barthelon, A.; El Kaïm, L.; Gizolme, M.; Grimaud, L. Eur. J. Org. Chem. 2008, 5974.

17. Cheng, X.; King Kuok, H. Tetrahedron 2001, 57, 5445. 